\title{
Investigating property damage along Dublin Port Tunnel alignment
}

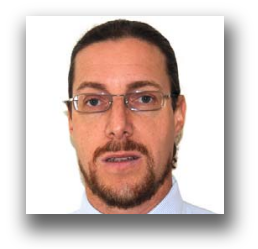

Andrea Gillarduzzi MSc (Hons), MSc (Lapworth Medal), DIC, EurGeol,

CGeol, EFG, FGS

Head of Geotechnical Engineering, High-Point Rendel, London, UK

During the winter of 2002/2003, Dublin City Council received various complaints regarding aesthetic and serviceability damage of several residential buildings located within the highly populated residential area of Marino (1.8 km northeast of Dublin centre, in the Republic of Ireland) allegedly caused by rock-tunnelling operations of the southwards tunnel-boring machine in the northbound tunnel carried out in execution of the Dublin Port Tunnel scheme. A holistic engineering-geological ground model for the area north of Dublin centre shows that structural elements crossing the bedrock have markedly affected the geological evolution and post-glacial drainage of the site, including the formation of buried valleys. A review of groundwater monitoring and tunnel construction records has allowed the causes of settlement at ground level to be identified. These include volume loss of the ground due to deformation and local failure of the tunnel excavation, dewatering of the bedrock and of coarse strata embedded in the Boulder Clay, resulting in the removal of fine soil particles, vibro-densification due to tunnel-boring machine ground-borne vibrations, and slow production and possibly consolidation of clayey strata. A comparison between the position of the properties where damages are being claimed and that of post-glacial rivulets and lakes, backfilled in the 1920 s following a rapid expansion of Dublin suburbs, clearly indicates a direct linkage between the two.

\section{Location and scheme overview}

The Dublin Port Tunnel (DPT) is a $5.6 \mathrm{~km}$ motorway scheme linking the Irish motorway network around Dublin to the northern part of the port (Figure 1). DPT comprises $1 \cdot 1 \mathrm{~km}$ of surface motorway and $4.7 \mathrm{~km}$ of twin tunnels, of which $2.8 \mathrm{~km}$ are bored and $1.9 \mathrm{~km}$ are cut and cover (Featherstone et al., 2003; Marshall and Goritshning, 2003).

This paper focuses on an approximately $1 \mathrm{~km}$ stretch of the DPT alignment excavated underneath the highly populated residential area of Marino (approximately between chainage $(\mathrm{Ch}) 2+700$, Grace Park Road and Swords Road and Ch 3+700, Croydon Park to the west of Griffith Avenue) using an $11.8 \mathrm{~m}$ diameter tunnel-boring machine (TBM) operating approximately $30 \mathrm{~m}$ below ground level.

The TBM southwards drive in the northbound tunnel began in early June 2002 and was completed by mid-July 2003, while the southbound tunnel excavation was protracted from October 2003 to August 2004. At Marino Park-Fairview (i.e. the study site), the twin rock TBM tunnels have a minimum separation of about $25 \mathrm{~m}$ and include two (40 m long) vehicle lay-by enlargements and a vehicle cross-over.

\section{The TBM}

The full-face shielded TBM was designed to excavate both glacial till and bedrock. The cutter-head included five 17 in
(432 $\mathrm{mm}$ ) double discs and 6317 in (432 mm) single discs. With this configuration, the TBM was capable of conducting unidirectional boring in a clockwise direction up to a maximum speed of $4 \mathrm{rev} / \mathrm{min}$. The $11.74 \mathrm{~m}$ diameter shield had an overall length of $8.79 \mathrm{~m}$ and weighed $1100 \mathrm{t}$. The thrust jacks system comprised 40 cylinders in five groups of eight, with a total thrust of $9378 \mathrm{t}$ of force and stroke of $2 \cdot 15 \mathrm{~m}$. The power rating for the TBM (including the back-up systems) was $4800 \mathrm{~kW}$. Probe drilling was mounted at one location close to the crown of the tunnel to allow investigations ahead of the advancing face. This was supplemented with a probe drill mounted on the segment erector to provide drilling around the tunnel periphery.

\section{Tunnel lining}

The lining of the tunnel includes a primary and a secondary lining separated by a waterproof membrane. The primary circular lining performs a structural function and constitutes the main waterproofing of the tunnel. This comprises bolted pre-cast concrete segments $1.7 \mathrm{~m}$ wide, $350 \mathrm{~mm}$ thick and $9.6 \mathrm{t}$ each (made of C60 concrete with approximately $90 \mathrm{~kg} / \mathrm{m}^{3}$ conventional reinforcement bars), with six principal segments and a key in each ring (Marshall and Goritshning, 2003). Below tunnel axis level, the lining consists of two nib segments (of which the inner lining is cast) and an invert segment. Owing to the nibs, the segment arrangement in the tunnel invert is 

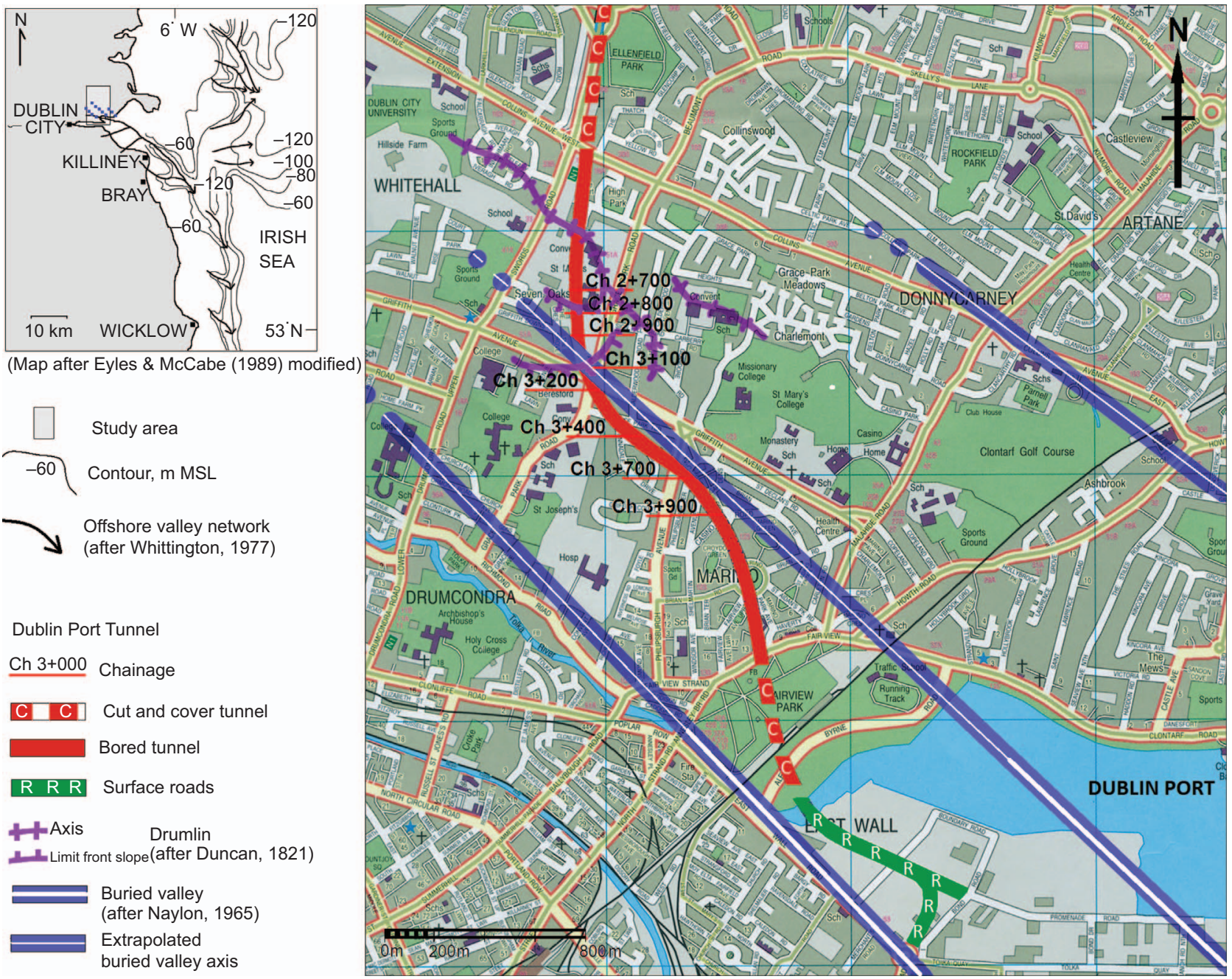

Figure 1. Site location and DPT alignment (inset: location of offshore buried valleys)

fixed and cruciform joints are formed. Above axis level, by alternating the position of the key, the segments are rolled by and the joints are staggered (Featherstone et al., 2003).

A single hydrophilic ( $22 \mathrm{~mm}$ wide, $5 \mathrm{~mm}$ thick strip) gasket was fitted on each segment. The gasket was installed in a customised groove towards the extrados on one segment, which was matched with a groove prepared opposite (during segment mould casting) in an adjacent segment. To permit the full efficiency of the gaskets, the installation of the rings required a high degree of accuracy and limited displacement tolerances. The maximum tolerance, for the $\pm 11 \mathrm{~m}$ internal diameter segmental lining, was $6 \mathrm{~mm}$ for lips and steps; the tolerance for the diameter, at any position, was limited to $\pm 50 \mathrm{~mm}$ and that for the packing for plane control limited to $2 \mathrm{~mm}$ (Featherstone et al., 2003).
The primary lining reduces the inner diameter of the tunnel from approximately 11.54 to $10.84 \mathrm{~m}$. Immediately, as the ring emerged from the TBM tail skin, the annulus between the excavation profile and the extrados of the tunnel lining (ideally $130 \mathrm{~mm}$ thick) was filled in two stages, with cement-based grout. The grout was injected at a pressure between 2 and 3 bars, through an aperture located in the middle of each segment; the injection pressure was regulated taking into account the dimensions the voids and degree of fracturing of the bedrock.

At the study site, production was on average seven rings per day. Cycle time to attain the seven rings was $1 \mathrm{~h}$ of excavation with a 45 min ring build.

The tunnelling contract required that the first lining had to be free from all leaks, seepage and damp patches for all areas 
above the carriageway and walkways. Below the carriageway and walkway level, the water ingress had to be restricted to minor damp patches with no visible film of water. To comply with these requirements, the primary lining was continuously inspected and works were not allowed to continue until any possible leakages or cracks were sealed with grout or resins and the lining was dry.

A second waterproofing layer was then installed to eliminate any possibility of water entering above the tunnel carriageway and walkways level. This included a $2 \cdot 1 \mathrm{~m}$ wide, $2 \mathrm{~mm}$ thick, polyvinyl chloride (PVC) membrane strips (with joints double term-welded and tested after installation at a pressure of 2 bars). The membrane was applied to the inside face of the primary lining by hot air welding onto PVC discs that were held in place by mechanical fasteners. On the ceiling of the tunnel, the fasteners were spaced at $0.5 \mathrm{~m}$ centre, but on the sides and base at $1 \mathrm{~m}$ centre. To prevent the future build-up of water pressure behind the secondary lining, a continuous geotextile was installed behind the impermeable membrane and the water was collected in a $250 \mathrm{~mm}$ internal diameter gravity drainage pipe located in the invert of the tunnel. The water discharged was monitored.

The secondary lining was installed above the carriageway and walkways level. This was designed to carry its own weight and that of the tunnel fixtures. This lining was cast against the waterproofing membrane from nibs realised in the primary lining. The lining included a nominal $275 \mathrm{~mm}$ thick layer of unreinforced, cast in situ, C40 concrete, with $1 \mathrm{~kg}$ of $18 \mu \mathrm{m}$ monofilament polypropylene fibres per cubic metre of concrete. The minimum structural thickness, after the specified tolerance, was $200 \mathrm{~mm}$. The secondary lining was installed to achieve a smooth finishing surface (to improve air flow, painting and cleaning), to protect the primary lining from tunnel fires and damage (due to impacts), and as a further waterproofing barrier to prevent water infiltrating above the carriageway. The finished internal tunnel diameter, including the secondary lining, was $10 \cdot 29 \mathrm{~m}$.

The installation of the waterproof membrane and of the secondary lining progressed as excavation continued, but was delayed by approximately 4 months.

\section{Buildings characteristics and reported damage}

At Marino, the TBM tunnels pass underneath more than 150 private residential dwellings, several shops and some institutional and private land (Figures 1 and 2). Most of these buildings were constructed between 1925 and 1929 and comprise two-storey houses in terraces of four, six and eight, plus a small number of semi-detached properties. The large majority of these buildings include a concrete ground floor and foundations, generally without reinforcing bars, and an upper timber floor. Various residential properties, especially in the past 30-40 years, have some form of extension work, including the construction of conservatories.

The pre-work building survey, undertaken within a $30 \mathrm{~m}$ wide corridor each side of the tunnel's sidewalls, located various noticeable defects in the main buildings and extensions. These were often related to poor-quality construction.

During 2002-2003, Dublin City Council received over 40 complaints concerning property damage and disturbance in the area of Marino, which were allegedly caused by rocktunnelling operations of the southwards tunnel-boring machine in the northbound tunnel. The most frequent complaints included: hairline cracks in plasterworks; cracks in ceilings, external and internal walls and ceramic tiles; hairline and shrinkage cracking of soft wood timbers and doors; pointing and grouting losses; doors not closing properly; and leaks through roof tiles and from water tanks and gutters. Other complaints related to cracks in garden walls and gas escapes, twisted floor boards, shaking fridges, noise and vibrations.

A further survey, carried out following the complaints, indicated that effectively 32 properties presented noticeable (i.e. aesthetic) defects and three serviceability damages limiting some functions of the building. The location of those properties is presented in Figure 2.

Dublin city council also received a number of complaints over damage to buildings located far away from the tunnel alignment, which clearly could not be related to the tunnelling works. The nature and extent of those damages (mainly cracks in the external walls and plasterwork) were consistent with those of the properties along the tunnelling alignment at Marino.

\section{Ground conditions}

The study site generally consists of, from ground level, 0-3 m of made ground (primarily clayey sand with rubble, glass and ceramics) and over $20 \mathrm{~m}$ of glacial and fluvial-glacial deposits concealing Carboniferous limestone. Laterally discontinuous soft to firm, sandy, silty, clayey, water-laid, alluvial sediments (max. $3 \mathrm{~m}$ thick) are locally lying on the glacial strata. The glacial deposits mainly include firm to very stiff, silty, sandy, gravelly clay (lodgement till) with sparse cobbles and boulders and (up to $5 \mathrm{~m}$ thick) embedded strata. The glacial deposits comprise lenses of fine to coarse sub-rounded to sub-angular gravel and cobbles with scarce, silty and fine, sandy matrix and occasional boulders (sub-glacial channels, fluvial-glacial, braided rivers and outwash deposits). The till is locally named Dublin Boulder Clay and it is traditionally subdivided into brown and black strata (Farrell et al., 1995). The brown layers are interpreted either to be the product of weathering of the black layers (Orr and Farrell, 1996) or to represent a different 


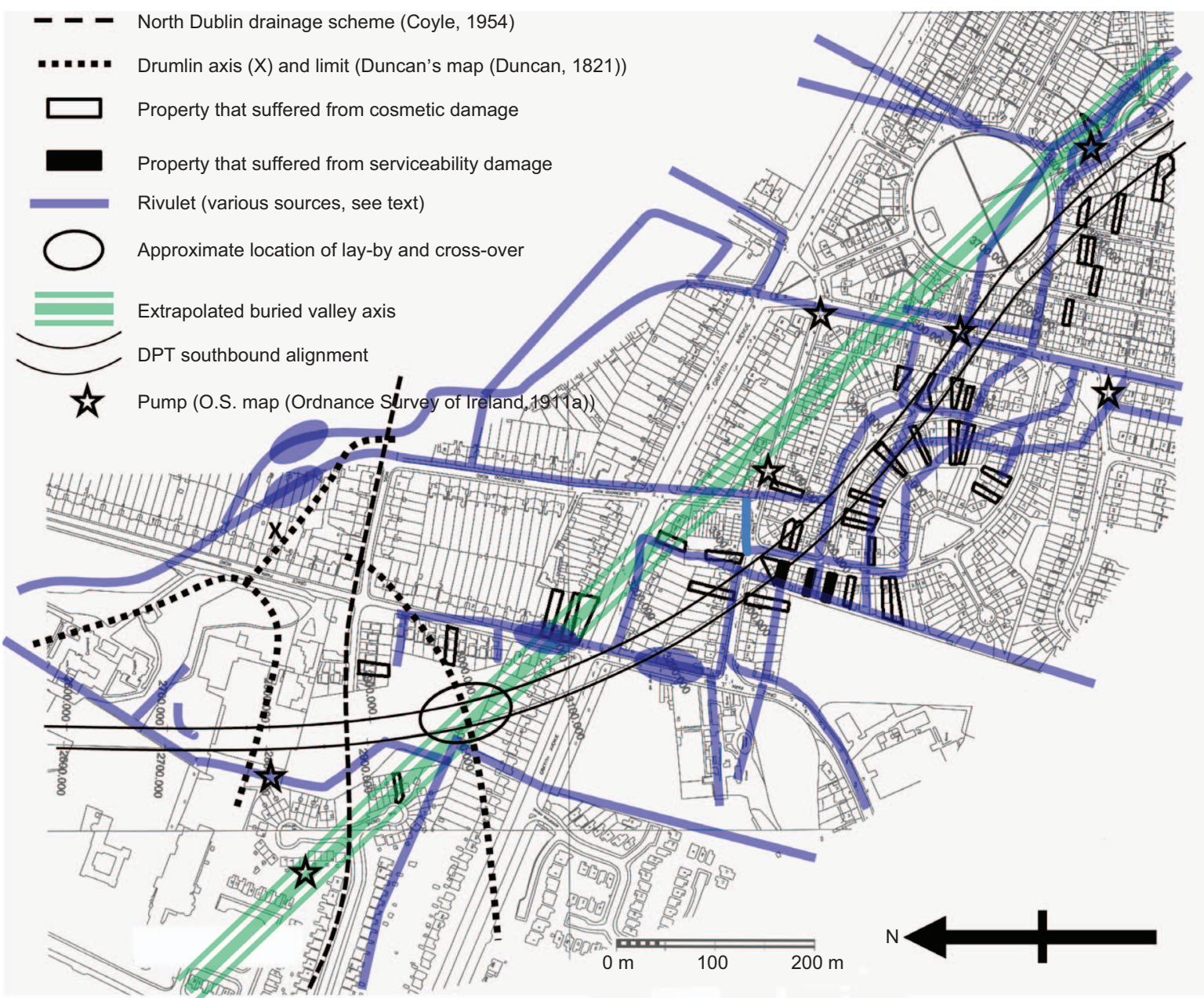

Figure 2. The study site

depositional feature (Hanrahan, 1977) or even a different glacial event. A detailed, updated description and interpretation of these strata, including their typical geotechnical properties, is given in Skipper et al. (2005) and Long and Menkiti (2007). The glacial strata were deposited, in various phases, on gently to tightly folded, faulted and glaciotectonised Lower Carboniferous Dublin Limestone.

The bedrock (basal part of the Lucan Formation), previously known as 'Calp' limestone (Nolan, 1989), comprises dark to light grey, fine-grained, strong to very strong limestone and argillaceous limestone (Marchant and Sevastopulo, 1980). The bedrock is thinly to thickly $(0 \cdot 1-1 \cdot 5 \mathrm{~m})$ bedded (typically $0 \cdot 3$ $0.7 \mathrm{~m}$ ), inter-bedded with soft, black, calcareous shale (mudstone) (Farrell and Wall, 1990).

At the study section, the TBM primarily worked through medium strength limestone with the tunnel crown located typically $3-8 \mathrm{~m}$ below the interface with approximately $20 \mathrm{~m}$ thick overburden. The ground surface and tunnel crown both generally fall southwards.

\section{Review of historic maps and literature}

The first settlements in Dublin date from approximately 2500 years ago and were located in proximity to the south bank of the River Liffey (de Courcy, 1996, 1998). Little, if any, building development existed on the north bank until approximately 1000 years ago (de Courcy, 2000). The first bridge to cross the River Tolka, north-east of Dublin centre, was built in AD 1313 (d'Alton, 1838). In the sixteenth century, the study site, which is located approximately $1.2 \mathrm{~km}$ to the north-east of the river, was disseminated with small ponds and lakes (see Rocque's map (Rocque, 2000) and Duncan's map (Duncan, 1821), as well as Ordnance Survey sheets from AD 1833 onwards), which 'survived' until approximately 100 years ago. At that time, the site was poorly drained and crossed by a reticulated 
network of rivulets that probably caused recurrent flooding following prolonged steady cyclonic rainfalls, as speculatively suggested by the origin of the name River Tolka (in Gaelic 'an tulca' means 'the flood') (Sweeney, 1991). Over the centuries, the study site was progressively reclaimed as farmland and the natural drainage was replaced by a reticulated pattern of ditches and canalised rivulets. The steady process of drainage and sanitation improvement intensified following the systematic provision of the sewers in Dublin from AD 1810 (Sweeney, 1991), the publication of the 'Bill for draining and allotting bogs of Ireland' in AD 1830 (British Parliament, 1830) and works to tackle the famine approximately 20 years later (Lohan, 1994)

Various historic maps (e.g. Davies, 1870; Duncan, 1821; Sollas, 1896) show the presence at the study area of a system of 'shalllow hills' with axis roughly elongated in a north-westsouth-east (NW-SE) direction (Figure 1). These hills probably originally stood metres higher than the surroundings, as also suggested by self-explanatory ancient locality names, which are mostly still in use today: Sand Hill, Sion Hill, Grace Park Heights, Hillside Farm, Hillcrest Park, High Gate, High Park, etc. The twentieth century urbanisation of the site has largely obliterated most of these features but, still today, Sion Hill Road and Grace Park Heights stand around 1-2 m higher than the surroundings.

The former location, at the study area, of rivulets, ditches, lakes, wells, ponds and 'elongated shallow hills' (obtained from O.S. sheets (Ordnance Survey of Ireland, 1833-1843, 1887, 1888a, 1888b, 1907, 1908a, 1908b, 1911a, 1911b, 1927-1928, 1935-1936, 1997, 1999); also see Coyle (1954) and Sweeney (1991)) is presented jointly (independently from their age) in Figure 2, overlapped on a recent map of the site. The position of these features is generally considered highly reliable, despite obvious difficulties in accurately geo-referencing the earlier information. The presence of various historic sub-parallel rivulets and ditches suggests that the original 'water courses' have been superimposed on progressively, and early diversions have been readjusted at various times (Sweeney, 1991), and probably used to mark property limits. The approximate orientation of ancient and present rivulets (of any sections of minimum $40 \mathrm{~m}$ length) within $1 \mathrm{~km}$ of the centre of the study site (independently from their length and water flow rate) is presented jointly in Figures 3(f) and 3(g).

\section{Tectonic evolution}

The tectonic evolution of the Great Dublin area comprises an early Carboniferous ( $\sim 340$ million years ago) stretching event (McConnell et al., 2000) resulting in sub-vertical NE-SW oriented faulting (Nolan, 1989). This led to the establishment of the faultbounded Dublin Basin. The study area is located approximately at the centre of the basin, where the syndepositional faulting was substantially less intense and extensive than in proximity to the ridges, resulting in limited faulting with this orientation.

Towards the end of the Carboniferous and possibly early Permian ( $\sim 300$ million years ago $)$ periods, a major tectonic phase (Varisican Orogeny) activated in response to a regional compression with NW-SE to NNW-SSE axis (Corfield et al., 1996; Johnston, 1993; McConnell et al., 2000). This phase caused (Cooper et al., 1996; Gill, 1962; Jones et al., 1988; Nolan, 1989; see also Geological Survey of Ireland (1995, 1999) map no. 13 and no. 16) folding with axis trending in NE-SW; dextral shear zones oriented in E-W to ENE-WSW strike; some N-S sinistral shear zones; and a high degree of deformation.

At the study area, the local pattern of shear faulting (mainly NNE-SSW $\pm 15^{\circ}$ to ENE-WSW strike and typical $75^{\circ} \pm 15^{\circ}$ south-east dip and NNW-SSE $\pm 15^{\circ}$ strike to NW-SE with typical $75-80^{\circ}$ east dip) is not always in accordance with the regional compression axis. This anomaly is probably due to the orientation of earlier local structures and depositional basins, as observed elsewhere by de Brit (1989) and Corfield et al. (1996) in the Irish Carboniferous strata.

The average tectonic axes for these two events, presented schematically in Figures 3(a)-3(e), have been derived from regional aerial photographic lineaments, recognisance of Carboniferous rock outcrops on the Irish Sea coast, quarries and random artificial exposures near Dublin, and the literature. Those axes have been confirmed by faults and joint sets recorded by DPT ground investigation, tunnelling logs and tunnel reflection tomography.

\section{Quaternary evolution}

At the end of the Tertiary period (approximately 1.8 million years ago), the present shape of Co. Dublin began to emerge, as well as the relief and drainage systems. The onset of the Quaternary period was marked by a dramatic change in climate. This caused an alternation of warm interglacial periods, having temperatures not unlike the ones of today (Farrell and Wall, 1990; Farrington, 1957), and long stages of very cold, glacial conditions (colloquially known as Ice Ages), with the cyclical growth and decay of glaciers and ice sheets. These climate changes have produced a geological record dominated by sediments deposited under temperate, periglacial and glacial environments, that is, by its very nature, a fragmentary one and consequently the subject of debate.

In Ireland, there is direct evidence of two glaciations (the penultimate 'Munsterian' and the latest 'Midlandian'), although probably there were a maximum of six (Warren, 1993). 

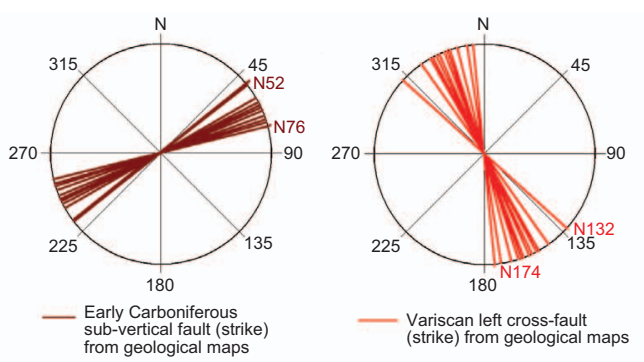

(b)

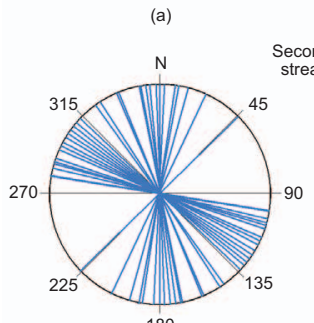

Approx. orientation of streams and rivulets,

located within $1 \mathrm{~km}$ from the study site
(independently from their length and water flow rate)

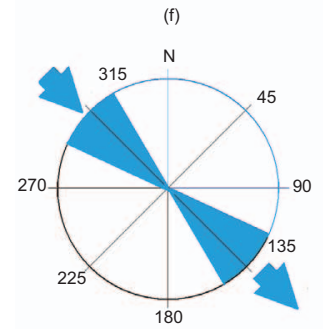

Midland glaciation direction

at the study site

(k)

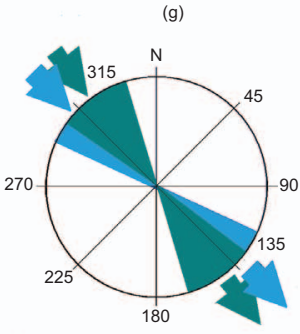

Midland glaciation direction
at the study site

rish sea slaciation

lrish Sea glaciation
at the study site

(I)
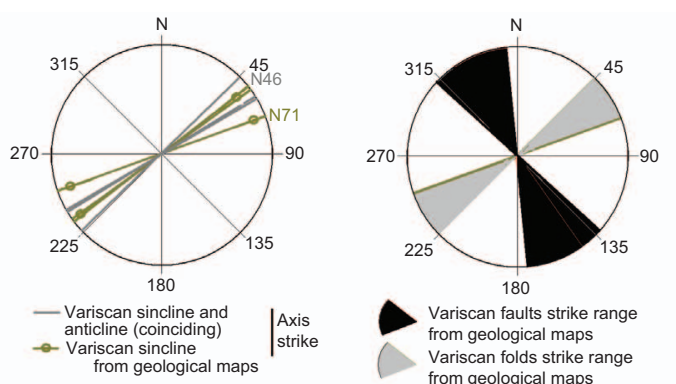

Variscan folds strike ran
from geological maps

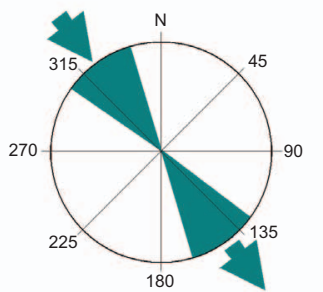

Irish Sea glacia Irish Sea glaciation
at the study site

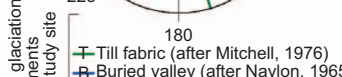

To $\frac{\text { Till fabric (after Mitchell, 1976) }}{0}$

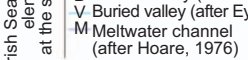

黑

(i)

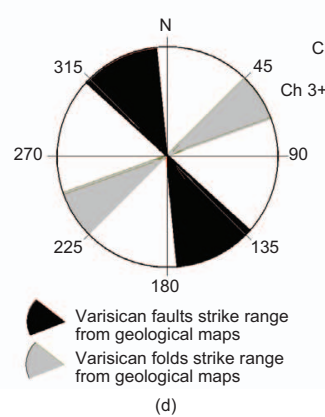

(d) (d)
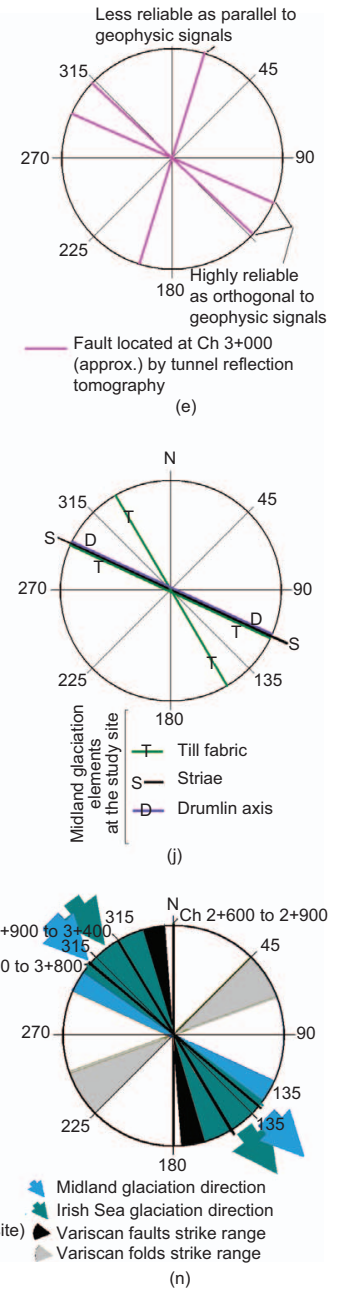

(m)

Figure 3. Stereonets showing the orientation of various features at the study site

Although various geomorphologic features are of indeterminate age and there are various exceptions, it can be generally assumed that the deepest drift deposits were laid during the Munsterian glaciation (McCabe, 1971, 1972). Most of the superficial drift and geomorphology in the central part of Ireland is related to the latest Midlandian glaciation. This covers a period of approximately 105000 years (from $\sim 115000$ to approximately 10000 years ago (Coxon, 1991)), with its maximum during the Late Devensian between 25000 and 15000 years ago (the 'Dublin Glaciation' of Hoare (1975) and the 'Glenavy Stadial' of McCabe (1987)).

It is generally accepted that, at the study area, the most significant glacial episodes are those related to the Irish Sea ice and ice sourcing from mainland Ireland (the 'Great Central Snowfield/ Irish Ice Sheet' of Synge (1969), see also Eyles and McCabe (1989), Knight and McCabe (1997), McCabe (1993); or the 'Northern Dome' of Warren and Ashley (1994)). The absolute dating of these events has yet to be achieved and even their relative ages are cause of dispute (Coxon, 2001) with numerous revisions and changes of nomenclature (Coxon, 1993; Hoare, 1975, 1991; McCabe, 1987; Mitchell, 1981).

During the Ice Age, most of the sediments were deposited by large ice sheets sourcing from a number of coalescing ice domes covering the northernmost part of the British Islands. The ice masses were dynamic with consistent changes in dome location, basal ice thermal regime and hydraulic gradient. Those combined factors controlled the sub-glacial processes and influenced the ice-marginal activity (Clark and Meehan, 2001).

In Co. Dublin, these glaciers were probably, at least for part of their history, of the 'warm' type (Coxon, 1993) with ice temperature close to the melting point throughout their depth 
and containing their own water tables. By definition, warm glaciers are generally fast moving (with average basal sliding velocity between 10 and $200 \mathrm{~m} /$ year) with efficient erosion, transport and production of a very large amount of meltwater during summer.

The Irish Sea ice (the 'Tullyallen ice sheet' of McCabe (1972)) was a large glacier or ice sheet (Warren, 1993). During the Munsterian (Farrington, 1957; Synge and Stephens, 1960) and Midlandian cold stages, it advanced south-westward from a major ice cap centred over northern Ireland and probably Scotland, extending over much of the present coastal lowland of Co. Dublin (McConnell et al., 2000). On shore, the activity of this and subsequent ice sheets is inferred from spatial patterns and directional components of landforms and sediments and, offshore, from boreholes and seismic evidence.

At the study area, the Irish Sea ice regional NE-SW ice movement direction derived from the literature (Charlesworth, 1928; Eyles and McCabe, 1989; Farrington, 1944, 1949; Hoare, 1975, 1977; McCabe, 1972, 1973, 1979; McCabe and Hoare, 1978) presents an exception, sweeping in the NW-SE direction. This change in direction is evident by the orientation of faceted pebbles (Hoare, 1975), buried valleys, till fabric (Skipper et al., 2005) and by literature relating to the counties located to the north of Dublin (Clark and Meehan, 2001; McCabe, 1993; Meehan, 1999). Those directions have been presented in Figures 3(h) and 3(i). The Irish Sea ice, at its maximum expansion, pushed against the Wicklow mountains, approximately $15 \mathrm{~km}$ to the south of Dublin, where the level of moraines and erratics (i.e. large boulders) suggests it had a thickness of at least 500-600 m (Hoare, 1975, 1977; Warren, 1993).

The Irish Sea ice was followed by the Midlandian ice (the 'Gilltown Glaciation' of McCabe (1972), the 'Dublin Glaciation' of Hoare (1975), the 'Dublin Ice Sheet' of Mitchell (1977), the 'Midlandian Stage' of Mitchell (1981), and the 'Late Devensian Glaciation' of Eyles and McCabe (1989)) originating from a centre located over $100 \mathrm{~km}$ to the north, in the midlands of Ireland. During this glacial event, a $1 \mathrm{~km}$ thick glacier (McConnell et al., 2000) moved south-eastwards on land across Co. Dublin, progressing towards the Wicklow mountains. In Ireland, over $90 \%$ of the superficial geomorphology is associated with this last glacial event (Knight, 2002, 2003) including striae and grooves cut into bedrock, roches montonneés (smoothened rock outcrops), faceted pebbles, till fabric, etc. As shown in Figures 3(j) and 3(k), those features are generally aligned consistently with the regional ice movement direction.

The orientations of these features in Co. Dublin, derived from literature and reconnaissance of available outcrops, are summarised in Figures 3(1). These clearly show that, at the study area, the prevalent $\sim \mathrm{NW}-\mathrm{SE} \pm 15^{\circ}$ alignment of the 'Irish Sea' and 'Midlandian' glacial features is generally consistent with the orientation of faults (Figures 3(d) and 3(n)). This clearly suggests that the regional faulting (and related ancient topography) provided a strong control on the ice flow. As a consequence, these geomorphologic processes strongly influenced local features, including the direction of post-glacial meltwater rivers and valleys and orientation of anisotropic deposition patterns of till and fluvial-glacial sediments, as well as related aquifers.

\section{Buried valley}

A complex regional network of U-shaped relic buried valleys, completely filled in by sediments at the present time, has been identified inland, south of Dublin (Hoare, 1977), and offshore by high-resolution seismic profiles across nearly $600 \mathrm{~km}^{2}$ of the western Irish Sea (Whittington, 1977) (Figure 1, inset). Three buried valleys have been located in the northern part of Dublin Port by Naylon (1965) and Hoare (1977) using almost 200 boreholes and geophysics surveys. At Dublin Port, the middle buried valley is over $300 \mathrm{~m}$ wide.

Ground investigations carried out in recent years (2006-2008) for the tender design of the planned Metro North Tunnel route indicate that the most southern of these three valleys extends several kilometres inland to the Drumcondra area (Figure 1).

Those valleys were carved into the bedrock by sub-glacial meltwaters driven by high hydrostatic head or by sediment-laden water escaping from the front of the glacier (Eyles and McCabe, 1989; Hoare, 1977). The exact age of the valleys' excavation is unknown but probably occurred during the early stages of retreat of the Irish Sea glacier (approximately 19000 years ago) and was possibly the result of the rejuvenation of earlier valleys.

As the DPT ground investigations were mainly carried out along the preferred alignment option, it has not been possible to 'map' those three buried valleys north of Dublin Port. A purely geometrical prolongation of the axis of the central valley northwards (Figure 1) shows that, in Marino, this feature runs almost parallel to the DPT alignment and intersects it (Figure 2). At approximately $\mathrm{Ch} 3+000$ (Figure 4), the profile of the top of the bedrock (derived from boreholes and geophysics) only shows the shape of a very shallow valley. However, at this chainage, the tomographic geophysical surveys have identified two very distinct major faults presenting very consistent orientation of the extrapolated buried valley (Figures 3(e) and 3(h)).

At Dublin Port, the bottom of the buried valleys includes $3 \cdot 5-17 \mathrm{~m}$ thick pebbly gravel overlain by glacial till and fluvial-glacial sediments. The nature of the coarse strata is consistent with that of strata found within a number of buried 
valleys located between Killey and Bray, $15 \mathrm{~km}$ south of Dublin Port, along the coast, see inset to Figure 1 (Eyles and McCabe, 1989). DPT ground investigations, carried out along the tunnel alignment (Figure 4), have identified expanses of glacial-fluvial sand and gravel embedded at various levels within the glacial till at chainages $\mathrm{Ch} 2+900$ to $3+000$ and $3+430$ to $3+800$ where the alignment intersects and runs close to the extrapolated buried valley axis, respectively (Figure 2).

\section{Groundwater}

The hydrogeological settings of the study area are not fully understood; however, in general, it can be assumed that the bedrock supports a nearly artesian aquifer confined or semiconfined by the aquiclude Boulder Clay. The Boulder Clay restricts the vertical recharge of the bedrock and allows the formation of perched streams and ponds at ground level.

The fluvial-glacial sands and gravels lenses and strata embedded within and beneath the Boulder Clay (Figure 4) are generally water-bearing and support perched aquifers, often with high interconnectivity and appreciable recharge. The drift aquifers can be independent or in hydraulic continuity with the bedrock.

The bedrock, in greenfield locations, presents an artesian piezometric level quite stable at $2.5 \mathrm{~m}$ above ground level and through the residential areas (that are built on fill) at $1 \mathrm{~m}$ below ground level. Pre-tunnelling ground investigation drilling records indicate that the bedrock piezometric levels sometimes coincided with those in the overburden, therefore suggesting the presence of a single aquifer. However, in other instances, the piezometric levels were inconsistent and the bedrock and the drift aquifers appeared to be completely separated and independent.

The piezometric monitoring carried out during the tunnelling works (that is described in detail hereafter) indicates that the excavation of the tunnel caused dewatering of both the bedrock and the overburden. In several instances, the bedrock and drift aquifers resulted in natural hydraulic continuity while, in some cases, the interconnectivity was possibly induced by the tunnelling works (see below).

At the study site, the interface between bedrock and overburden is either gradational (sound rock/fractured rock/drift) or sharp (sound rock/drift) and the overburden includes Boulder Clay, fluvial-glacial sand and gravel or esker deposits (Figure 4).

In northern Dublin, the permeability of the bedrock below the interface with the overburden is highly variable from site to site (McConnell et al., 2000), as also confirmed by in situ permeability test at $\mathrm{BH} 212, \mathrm{BH} 214$ and $\mathrm{BH} 218$ (see Figure 4 for location). In general, the bedrock permeability decreases

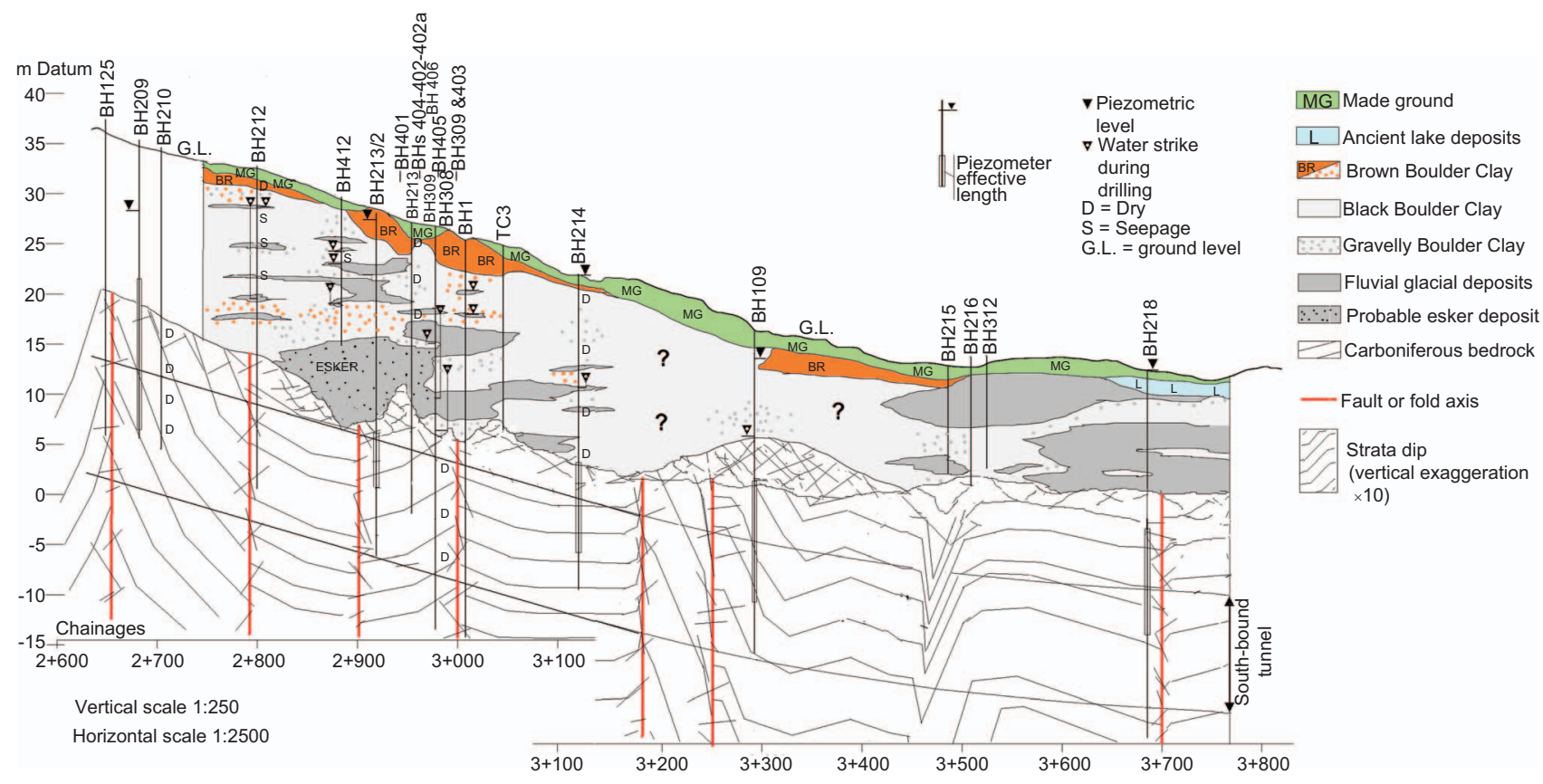

Figure 4. Geological cross-section along the northbound tunnel's longitudinal axis 
with depth passing from $10^{-5}$ to $10^{-8} \mathrm{~m} / \mathrm{s}$ over a distance of less than 3-8 $\mathrm{m}$ below the interface with the drift.

The bedrock is generally a poor aquifer (Creighton et al., 1979) (i.e. low primary permeability), except where the effect of tectonics is severe, such as along faults or at the crests of tight folds (i.e. high secondary permeability). Therefore, the closer the tunnelling is to the bedrock/drift interface (e.g. as at the bottom of a buried valley following a fault), the higher the potential of encountering high-permeability bedrock and high water inflows. The bedrock generally presents high clay content (Sevastopulo, 1996) and therefore it does not develop karstic cavities.

Figure 4 presents the level of the water strikes recorded during DPT dedicated ground investigations. Although these records are sparse, they indicate that the gravel/sand strata embedded in the Boulder Clay have generally inconsistent piezometric levels, and that apparently continuous large sand/gravel bodies sometimes support a number of independent aquifers. This is fully consistent with the fact that those coarse strata were laid by braided rivers that are typical for the presence of various independent channels within a main, larger, river bed (Figure 5).

Works along the DPT cut and cover section and at a $56 \cdot 6 \mathrm{~m}$ diameter shaft (both located north of the study site) showed that sand lenses (embedded in the Boulder Clay) were supporting perched aquifers that caused problems of running ground conditions during the excavation (Featherstone et al., 2003).

Pumping tests and piezometer monitoring have not made it possible to systemically ascertain whether the various gravel and sand strata are interconnected, and in general did not provide particularly relevant information regarding the overburden aquifers. The limited piezometeric monitoring data (that mostly refer to the overburden/rock interface) do not allow the definition of any certain inflow or outflow boundaries of the drift aquifers.

The permeability of undisturbed Boulder Clay (with low gravel content) is in the range $10^{-9}$ to $10^{-11} \mathrm{~m} / \mathrm{s}$ while that of Boulder Clay with high gravel content is up to $10^{-6} \mathrm{~m} / \mathrm{s}$.

The minimum permeability of fluvial-glacial strata is $10^{-5} \mathrm{~m} / \mathrm{s}$. When those strata are in hydraulic continuity with the bedrock they provide a high level of recharge and storage.

The permeability of the made ground and of the superficial water-laid strata has not been defined but it can be considered variable and strongly anisotropic (vertical permeability $<<$ horizontal permeability) and probably within the range of $10^{-3}$ to $10^{-7} \mathrm{~m} / \mathrm{s}$.

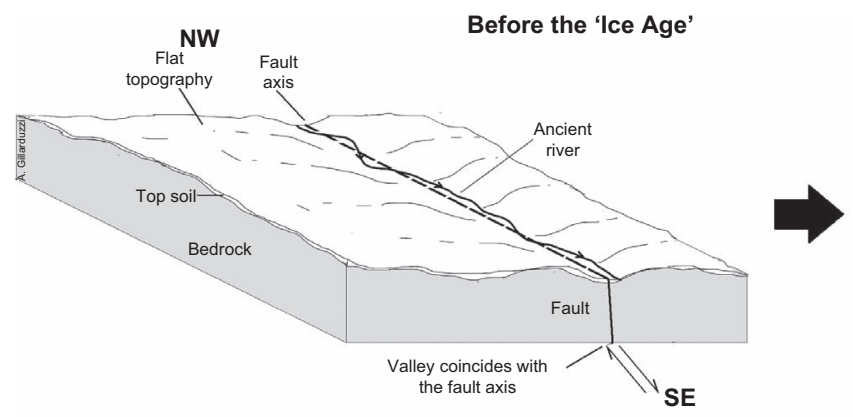

Not to scale

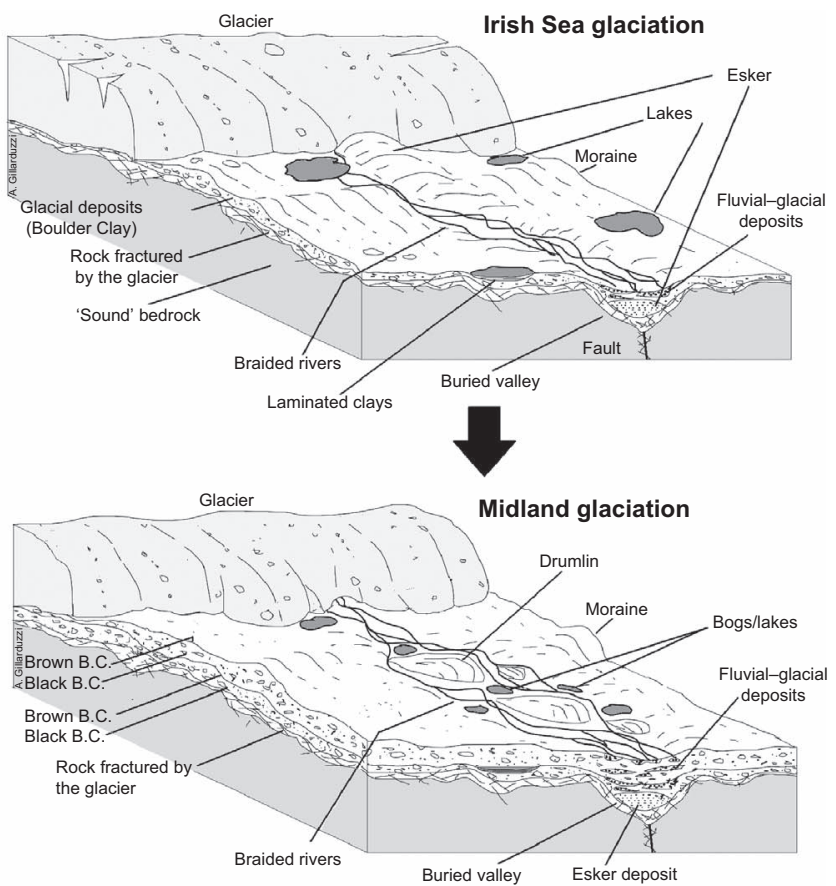

Figure 5. Ground model of the site showing part of its Quaternary evolution 


\section{Engineering geological model}

In Co. Dublin, during the period immediately preceding the socalled Ice Age, the continental ice sheets stored most of the water as ice and consequently the sea level was markedly lower than the present level. The land stood at almost the same level as today (Cater, 1982; Wright and Muff, 1904) and was characterised by weathering and erosion of limestone at rockhead level (Long and Murphy, 2003), as presented in Figure 5. Valleys were probably running along ancient fault lines, where the bedrock was naturally more fractured and weaker, and rivers had the enhanced tendency of eroding towards the lowered sea level.

From about 120000 years ago, the approximately $600 \mathrm{~m}$ thick (Warren, 1993) temperate Irish Sea ice sheet advanced on the study site in the $\sim$ NW-SE direction (Figures 3(h) and 3(i)). The movement of the lower level of the approaching ice sheet was conditioned by major features in the topography (McConnell et al., 2000) (Figures 3(b) and 3(d)) and therefore affected by already present valleys exploiting the ancient fault lines (Figures 3(n) and 5).

During the glacial period, in Dublin, at medium latitude $\left(\sim 53^{\circ} \mathrm{N}\right)$, the climate was cold but with the possibility of ice melting during the summer nevertheless. The glaciers and the supplementary large volumes of meltwaters tectonised (i.e. fractured) and carved the bedrock surface, rejuvenating and/or deepening existing rivers, sub-glacial and pro-glacial valleys. A complex network of buried valleys is today located offshore in the Irish Sea and at Dublin Port (inset to Figure 1) and extends onshore (Figure 1). The Irish Sea glacier, during its life, had various advances and withdrawals, due to cyclic climate warming. Those phases were accompanied by deposition, followed by partial erosion, of lodgement till (the 'lower brown and black Boulder Clay - subunit A and B' of Skipper et al. (2005)), sheet-flood deposits and lake/shallow estuarine laminated sediments (the 'lower black Boulder Clay subunit C' of Skipper et al. (2005)), (Figure 5). The ice also determined the movement of meltwater as it supplied a mould created within water-worn deposits (Sollas, 1896).

During and following retreat of the Irish Sea glacier, glacial till and sediments were deposited by meltwater rivers progressively filling in the valleys (Figure 5). These coarse sediments and the relative aquifers are consequently elongated in an average NW-SE direction consistently with axes of advanced and retreat of the ice.

The Irish Sea glacier was followed by the $1000 \mathrm{~m}$ thick Midlandian 'glacier', which crossed Co. Dublin south-eastwards (Figures 3(j) and 3(k)).

The Midlandian glaciation was not straightforward, with local withdrawals of the ice followed by re-advances. This resulted in a complex depositional system beneath and around the ice sheet. As for the previous glacial event, every advance phase eroded, glacial-tectonised and remoulded the existing glacial and fluvial-glacial sediments and deposited new widespread drapes of diamicton and lodgement till (the 'brown and black Dublin Boulder Clay' of Farrell et al. (1995), and 'upper brown and black Boulder Clay' of Skipper et al. (2005)). Those glacial sediments are variable in nature but most are a massive till with subordinate lenses, bars and levels of outwash and fluvialglacial sediments. and possibly also glacial-marine strata.

Towards the end of the glacial period, from approximately 20000 years ago, the temperate Midlandian glacier progressively withdrew, and probably approximately 14500 years ago (Coxon, 1993; McCabe and Clark, 1998), a system of drumlins (i.e. elongated drop-shaped hills) (Figures 1, 2, 3(j) and 5) predominantly composed of clayey or silty till was deposited.

The literature (McCabe, 1987; Sollas, 1896; Synge, 1979) indicates that a system of eroded drumlins, with axis roughly elongated in a NW-SE direction, intersects the tunnel alignment between $\mathrm{Ch} 2+300$ and $\mathrm{Ch} 3+050$ at ground level (Figures 1, 2 and $3(\mathrm{j}))$. It is noted that at this site, which is consistent with several sites in eastern Ireland, drumlins are 'associated' with up to a maximum $30 \mathrm{~m}$ thickness of glacial deposits (McConnell et al., 2000). The drumlins were originally standing probably several metres higher than the rest of the area, whereas now, following over 10000 years of erosion and human activity, including quarrying, they are just $1-2 \mathrm{~m}$ higher than the surroundings. The deposition of drumlins caused poor drainage in the inter-drumlin land (Figure 5), leading to the formation of hummocky ground and ponds elongated mainly in a roughly NW-SE direction (Figures 3(f) and 3(j)). This pattern has also been found to the north of the study area at Co. Meath and Cavan (McConnell et al., 2000) and elsewhere in Ireland (Sollas, 1896).

After the retreat and decay of the glaciers, various ponds and lakes formed in depressions in the impermeable and frozen (i.e. permafrost) glacial till and in kettle holes (Figure 5). Since their formation, some of the post-glacial ponds and lakes have progressively been naturally filled with sediments and vegetation evolving in bogs, while others were partially drained by a new network of streams and rivulets. Less than a century ago, some of those features were still present at the study site. DPT ground investigations have encountered laterally discontinuous strata and lenses close to ground level (up to $3 \mathrm{~m}$ thick) of soft to firm, silty, sandy, clayey sediments with high organic content and laminated clays deposited in these environments.

At the end of the Ice Age, the ice sheets began to melt, returning the vast amount of water to the oceans, and the sea level rose from approximately $-120 \mathrm{~m}$ Ordnance Datum 
(Coxon, 2001) to roughly the present coastline that stabilised more than 5000-4000 years ago (Devoy, 1983; McConnell et al., 2000; Mitchell, 1981, 1987). The modern fluvial system is superimposed upon, and largely controlled by, eustatic variation of the sea level, isostatic depression caused by the weight of the ice, and in particular the pre-existing glacial landscape that was, in turn, exploiting the tectonic axis (Figures 3(d), 3(g) and 3(1)).

Since at least three centuries ago, the study site has been progressively drained and reclaimed by farmland, with the main urbanisation dating from 1925 to 1929, following a fast expansion of Dublin's northern suburbs. This has resulted in most of the ponds (e.g. Sion Hill pond $\sim$ Ch 2+650; Croydon Park Avenue pond $\sim \mathrm{Ch} 3+800$ ) being backfilled; streams and ditches diverted, filled or piped underground and used as sewer mains (Sweeney, 1991); woods cut; and in general the ground levelled and landscaped (Figure 5). The literature and DPT ground investigations indicate that, during this period, large blocks of houses were built over a short period of time on made ground fill, locally up to $3 \mathrm{~m}$ thick, without preventive stripping of topsoil, removal of stumps or excavation of soft and compressible water-laid sediments.

At the study site, in the past $70-80$ years, the location of the dual carriage ways and main roads has not substantially changed.

\section{Settlement contour map}

The ground settlement contour map, presented in Figure 6, is based on surface monitoring data within a $30 \mathrm{~m}$ corridor each side of the TBM northbound tunnel sidewalls. The settlement data were collected by precise levelling technique at completion of the tunnelling works (including installation of primary lining) along the study section. The field data were elaborated using a linear variogram isotropic model to identify the best possible model for the set, prior to geo-statistical spatial analysis by Kriging and final contour plot using proprietary software.

It is noted that the ground model presented above indicates that tectonic, geological and hydrogeological settings of the study area are markedly anisotropic (Figure 3). Therefore, the isotropic assumptions originally adopted for the elaboration of the factual data are not necessarily fully representative of the effective site conditions and have probably resulted in 'distorted' settlement contours compared to reality.

\section{Causes of settlement at the study site}

The DPT tunnelling works have caused measurable settlement at ground level (Figure 6) due to a number of overlapping mechanisms. These are described in the following subsections.

\subsection{Volume loss}

Volume loss of the ground has been caused by local failure and deformation of the tunnel excavation. Volume loss was greater where the tunnel alignment intersected:

faults and the axis of very tight chevron folds;

- difficult ground conditions (e.g. rock rich in expansive clay);

thinly bedded plastic mudstone (rather than thicker and stiffer limestone strata); and

areas with thin and fractured rock cover above the tunnel crown (e.g. where the axis of the buried valley intersects the tunnel alignment).

The large majority of the local failures are due to unstable rock 'wedges' resulting from the intersection of (existing or tunnelinduced) bedrock joints and the excavated tunnel profile (before construction of the primary lining).

Other failures are due to mechanical failure of unsupported bedrock before primary lining construction. During tunnelling works, using a very simplified model, the bedrock on the face of a bored tunnel is subjected to a vertical overburden pressure $\left(\sigma_{1}\right)$ without lateral confining pressure $\left(\sigma_{3}=0\right)$. Figure 7 presents in a simplified manner the load stresses at the unsupported face of the tunnel (for a typical site in Marino area) together with failure envelopes (using Mohr-Coulomb criterion) for weathered/ damaged and 'sound' local bedrock. Figure 7 shows that the envelope for 'sound' rock does not intersect the Mohr-Coulomb circle and therefore the bedrock above the crown of the tunnel is likely to arch and beam, resulting in very limited tunnel volume loss and settlement at ground level. In contrast, the failure envelope for weathered/damaged bedrock intercepts the MohrCoulomb circle, therefore indicating failure of the bedrock above the tunnel crown, resulting in accentuated volume loss and consequent settlement at ground level.

Along the entire tunnel alignment, it was found that the mudstone strata, which are substantially more plastic (Figure 9(b)) than the limestone, result in virtually no overbreaks during tunnelling but more intense relaxation and deformation of the tunnel profile, and comparatively greater settlement at ground level.

\subsection{Dewatering of deposits and bedrock}

Another mechanism responsible for settlement is the dewatering of coarse fluvial-glacial and esker deposits (embedded or lying underneath the Boulder Clay) and of large bodies of highly fractured bedrock. The dewatering caused removal of 'fines' (i.e. clay to sand sized particles) and consequent volume loss of the ground located above the crown and flanks of the tunnel excavation. During tunnel excavation, larger water inflows were recorded where the bedrock was intensively jointed and weathered (e.g. faults, tight folds, axis of the buried valley, and bedrock at the interface with the drift). The water 


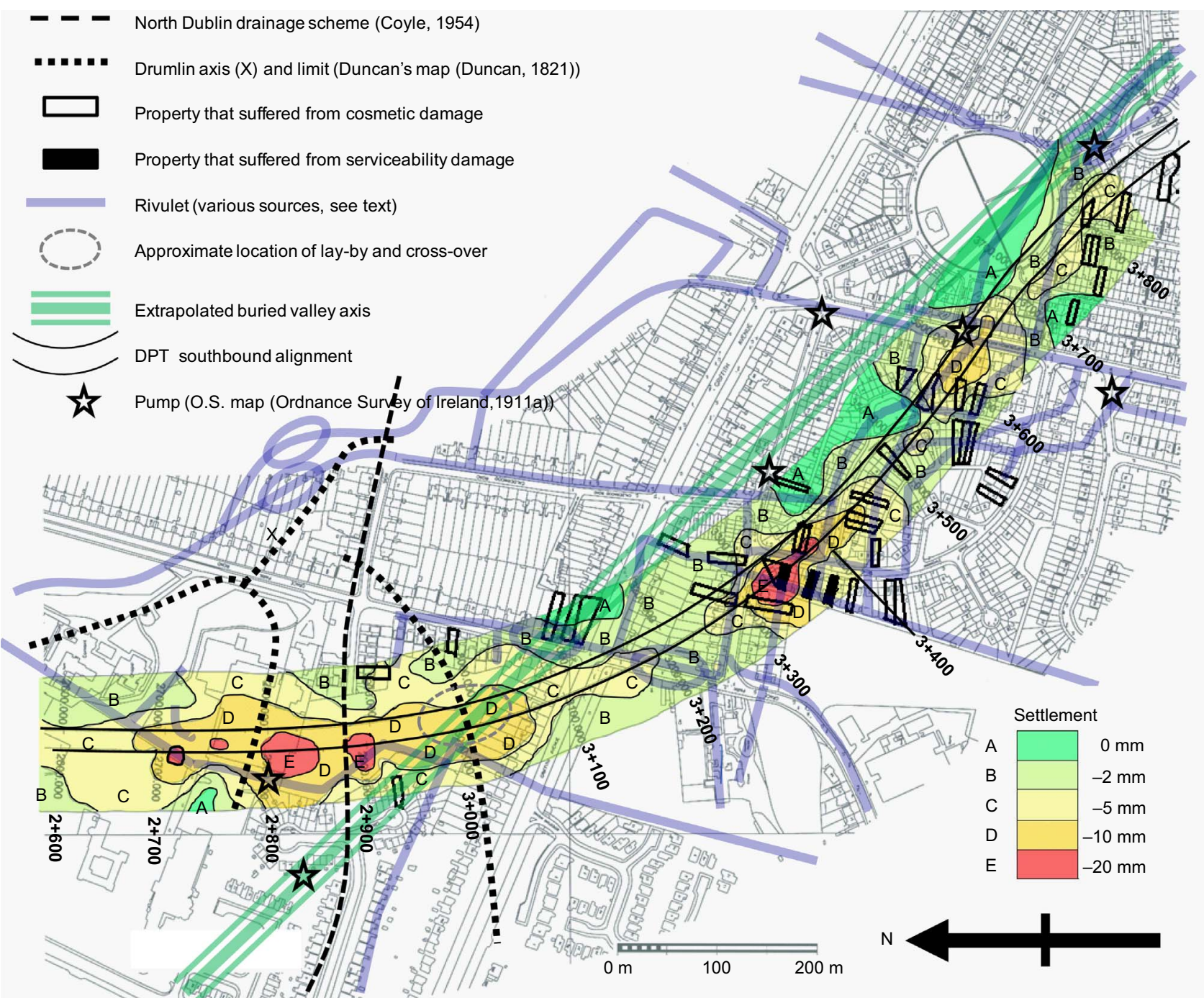

Figure 6. Map of recorded settlement at ground level following southwards tunnelling

inflow was found to be extremely variable, passing from dry rock to medium inflow (say over $300 \mathrm{l} / \mathrm{min}$ ) to dry rock within a few metres of tunnelling. In-person observations in July 2003 , during the construction of a number of service niches in the primary lining between $\mathrm{Ch} 3+700$ and $3+800$, found that the inflowing groundwater was cloudy and contained fine to medium sand particles (arising from the drift strata) that had managed to percolate through over $9 \mathrm{~m}$ of bedrock above the tunnel crown down to the tunnel flanks.

\subsection{Vibro-densification}

This subsection describes the mechanism of vibro-densification of open structure (i.e. medium-porosity) coarse deposits embedded within the Boulder Clay (and/or of superficial strata) by the combined action of dewatering (causing removal of fine soil particles and de-pressurisation of confined aquifers) and ground-borne vibrations from the TBM. The combined effect is the densification of the soil with reduction of porosity and consequently of volume. The mechanism is schematically illustrated in Figure 8.

In order to demonstrate the possibility of this mechanism, the in situ porosity of the sand and gravel strata embedded in the Boulder Clay has been back-calculated using in reverse the Kozeny-Carmen equation (as given in Bear (1972)). This particular formula (see below) had been successfully adopted to identify the in situ permeability of tills at a site located $10 \mathrm{~km}$ north of Marino (Swartz et al., 1999). 

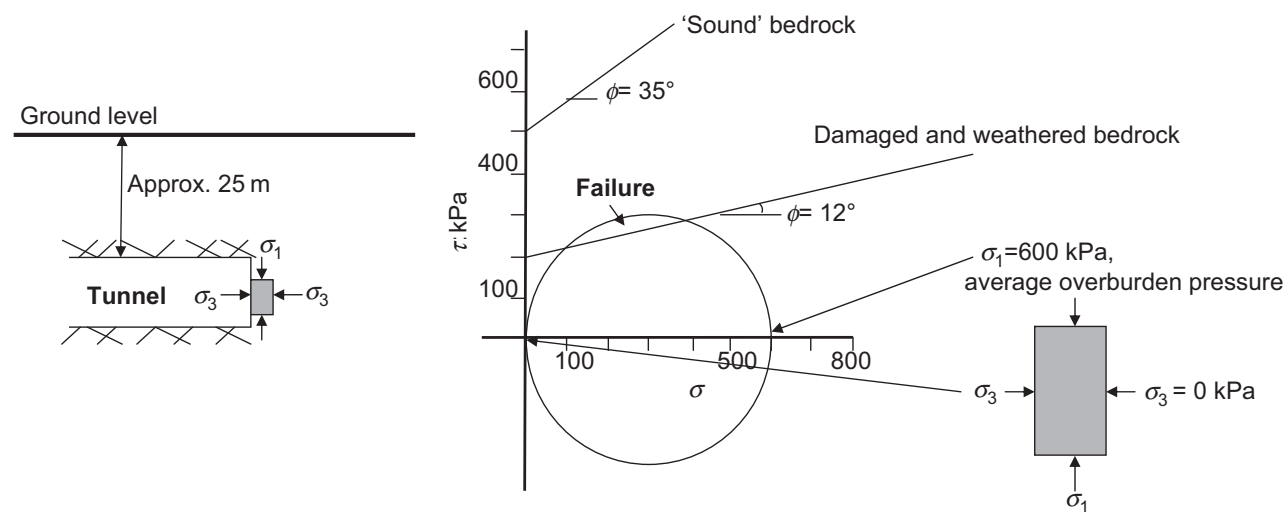

Figure 7. Stresses acting on an unsupported tunnel face and 'sound' and weathered/damaged bedrock failure envelopes using Mohr-Coulomb criterion

$$
K=10\left[\left(d_{10}\right)\left(180^{-1}\right)\right]\left[\left(n^{3}\right)\left(1-n^{2}\right)^{-1}\right]
$$

where $K$ is the in situ permeability $(\mathrm{m} / \mathrm{s}$ ) (in this case derived from site-specific pumping tests in the water-bearing sand and gravel strata); $d_{10}$ is the particle diameter (m) corresponding to $10 \%$ cumulative (from 0 to $100 \%$ ) undersize particle size distribution (from site-specific particle size distribution laboratory tests); and $n$ is porosity.

The back-calculated porosity of the water-bearing sand and gravel strata ranges between $25 \%$ and $35 \%$, thus indicating that these sediments have a relatively open structure which is typical of materials deposited by high-energy glacial braided rivers.
The nature and intensity of ground-borne vibrations, in terms of the peak particle velocity, generated by the DPT TBM and transmitted through the ground, are discussed in Rahman and Orr (2011).

\subsection{Dewatering causing consolidation}

It is plausible that dewatering of coarse strata has caused some degree of consolidation of overlying Boulder Clay and superficial normally consolidated clay (i.e. made ground, organic strata, water-laid strata and highly weathered, superficial Boulder Clay). However, it is noted that the settlement contour map (Figure 6) refers to the settlement that occurred shortly after the tunnelling works. It is believed that only a very limited

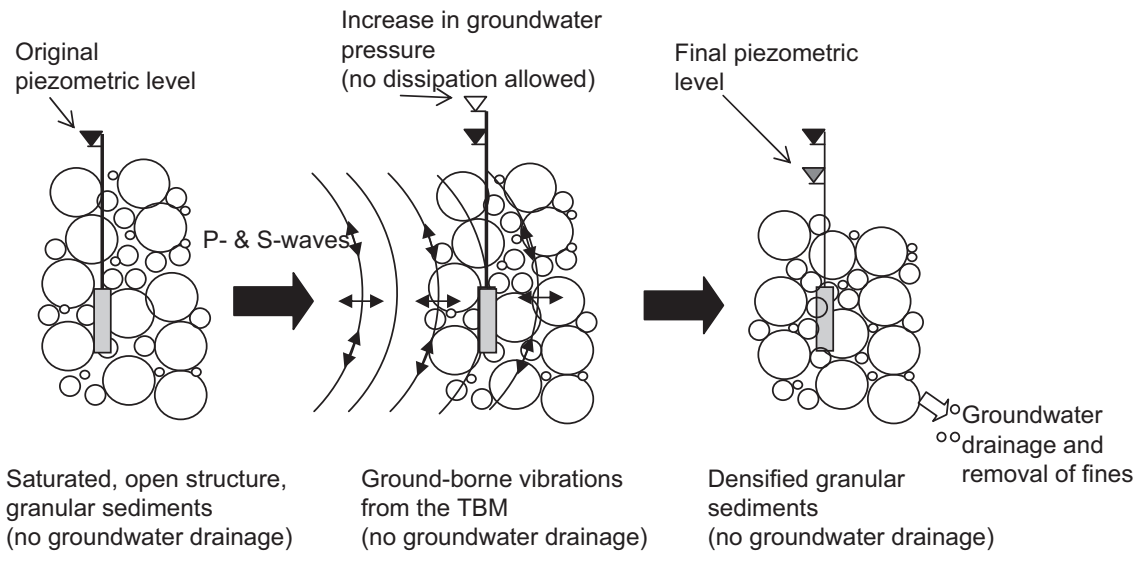

Figure 8. Effect of combined ground-borne TBM vibrations and dewatering on coarse, water-bearing sediments, resulting in densification of the soil 
amount of settlement could have developed in the short time between the first occurrence of dewatering ahead of the excavation and completion of the tunnel primary lining works (i.e. say a maximum of 1 month).

The comparison of the geological cross-section (Figure 4) and the settlement contour map (Figure 6) indicates that the areas affected by the greatest amount of settlement appear to coincide with the presence of well-developed (i.e. thick and highly weathered) brown Boulder Clay close to ground level. In those areas, the piezometric records indicate that the tunnelling works have caused dewatering of the coarse drift located underneath the brown Boulder Clay, probably causing removal of fine soil particles and possibly some degree of consolidation of Boulder Clay and superficial clayey strata.

The comparison between Figure 2 and Figure 6 indicates that there are not any systematic correlations between the amount of settlement ( $0-20 \mathrm{~mm}$ range) and the location of rivulets and ponds. However, areas affected by settlement over $5 \mathrm{~mm}$ lay very close to backfilled rivulets. Therefore, it is believed that consolidation of pond and rivulet strata is more likely to have occurred where settlement, due to DPT tunnelling works, had already occurred, triggering the dewatering of strata close to ground level (see below regarding settlement at $\mathrm{Ch} 2+739$ and Figure 10 in Section 14).

\subsection{Slow tunnel production}

When the TBM approached the residential area of Marino, working hours were reduced from 24 to $16 \mathrm{~h}$, and then down to $13 \mathrm{~h}$ per day, in order to limit noise and disturbance to residents. As result, the rate of production was reduced (including the installation of waterproofing) and the tunnel front face remained unsupported for longer periods. This inevitably allowed greater relaxation and more intense dewatering of the ground, both of which are generally conducive (especially where the rock cover over the crown of the tunnel is thin and damaged) to greater settlement at ground level.

At the study site, slow tunnel production was further locally exacerbated by the presence of highly fractured rock, expansive clays and low tolerance of hydrophilic gaskets of the primary lining.

\section{Cause of settlement and tunnel construction records}

Within the study site (Figure 6), settlement at ground level was 'greater' (i.e. 5 to $20 \mathrm{~mm}$ ) along three sections, namely Ch $2+675$ to Ch $3+060$, Ch $3+275$ to $\mathrm{Ch} 3+455$, and Ch $3+585$ to $\mathrm{Ch} 3+670$. The causes of settlement along the study site are described thereafter from $\mathrm{Ch} 2+600$ southwards consistently with the tunnelling works direction.
Settlement at ground level between approximately Ch $2+600$ and $\mathrm{Ch} 3+190$ was related to a number of overlapping and concatenated causes. These mainly included volume loss (due to fractured bedrock, thin rock cover, local instability of the excavated section, etc.) in combination with subordinated dewatering and slow tunnelling progress. The settlement was greater from $\mathrm{Ch} 2+675$ to $\mathrm{Ch} 3+060$.

One of the causes for the 'greater' settlement along this section of the tunnel is found in the fact that this intersects with the extrapolated axis of the central, glacial, buried valley found in Dublin Port (Figures 1 and 2). Buried valleys are notoriously considered unfavourable to tunnelling, leading to greater settlement at ground level than the surroundings.

For example, in 1926, the excavation of the shaft for a sewage tunnel under the River Liffey, from Ringsend to the North Walls, less than $1 \mathrm{~km}$ to the south of Marino, crossed sand and gravel beds infilling one of the buried valleys running beneath Dublin Port (Nicholls, 1929). This resulted in substantial problems in maintaining the stability of the excavation and considerable settlement, which caused major serviceability damage to nearby buildings.

Along this section of the tunnel, owing to the presence of the buried valley, the thickness of the rock cover above the crown of the tunnel is very limited (Figure 4) and the bedrock is highly fractured and damaged. This caused volume loss of the ground due to a number of localised failures of the bedrock located above the crown and along the flanks and front face of the tunnel. The large majority of those are due to the formation of unstable 'wedges' of rock (caused by the intersection of existing joints and the excavated tunnel profile) and a much smaller proportion by mechanical failure of unsupported bedrock before primary lining construction.

Between Ch $2+724$ and $\mathrm{Ch} 2+788$, the TBM caused a number of overbreaks. For instance, at $\mathrm{Ch} 2+727$ (rock cover above the tunnel crown approx. $6.3 \mathrm{~m}$ ), overbreaks included $0.5 \mathrm{~m}$ on the crown, $2 \mathrm{~m}$ ahead of the face and $1.5 \mathrm{~m}$ on the side face (and the bedrock was damp). At $\mathrm{Ch} 2+734$ (rock cover approx. $6 \mathrm{~m}$ ), the overbreak ahead of the cutter-head was $2-2.5 \mathrm{~m}$ with $120 \mathrm{l} / \mathrm{min}$ water ingress through the joints.

Between Ch $2+739$ and $\mathrm{Ch} 2+742$ (rock cover above the tunnel crown approx. $5.9 \mathrm{~m}$ ), the TBM excavated through what the tunnel face $\operatorname{logs}$ described as a NE-SW striking fault/shear zone. Limestone blocks in this area were sub-rounded and loosely bedded, with much fault gouge infilling limestone bed and joints. The rock was also crosscut by many calcite veins. Between Ch $2+742$ and $\mathrm{Ch} 2+788$, the bedding became more competent, dipping approximately $60^{\circ}$ to the SE. The reported NE-SW orientation of this structural element, compared to the 
tectonic axis presented in Figures 3(c) and 3(d) (and similar features found southwards of this chainage as the tunnel progressed), suggest that the tunnel crossed a very tight 'chevron' fold.

Folds of this type, and associated joints, are visible at an outcrop at Loughshinny Bay (Figure 9(a)) along the Irish coast, $20 \mathrm{~km} \mathrm{N-NE}$ of the study site. This outcrop (Figure 9(b)) also clearly shows the very different behaviour of the stiff limestone strata compared to the thinly stratified mudrock. The former reacted rigidly to the imposed compressive stress (Figures 3(c) and 3(d)), developing a number of joints (now calcite veins), whereas the mudrock accommodated the imposed stresses by deforming plastically.

When the TBM crossed the fold axis at $\mathrm{Ch} 2+739$, due to high fracturing, a large dice-shaped block of limestone ( $c$. $0.3 \times 0.3 \mathrm{~m}$ ) fell into and jammed the TBM cutter-head and damaged the conveyor. This caused slow and problematic advance of the TBM (i.e. $8 \mathrm{~d}$ to excavate $37 \mathrm{~m}$ of tunnel

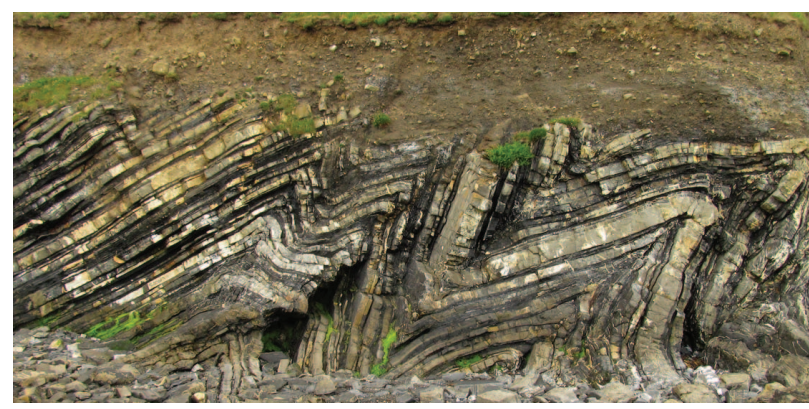

(a)

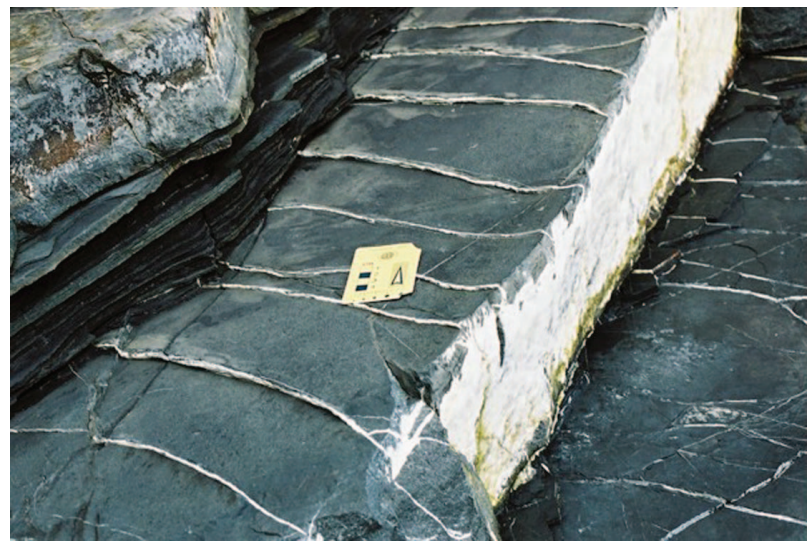

(b)

Figure 9. Loughshinny Bay (Dromanagh Head), Irish coast, $20 \mathrm{~km}$ N-NE of the study site: (a) natural outcrop of chevron-folded Carboniferous limestones and mudrock/shales overlain by glacial till and topsoil; (b) outcrop detail showing thickly bedded limestone crossed by calcite veins and thinly bedded mudrock/shales between $\mathrm{Ch} 2+742$ and $\mathrm{Ch} 2+779$ ), which is likely to have favoured greater volume loss of the ground and settlement at ground level.

After the TBM had intersected the tightly folded area at Ch $2+739$, for 11 days, the piezometers installed up to $260 \mathrm{~m}$

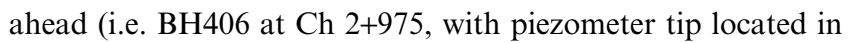
the drift, and BH401 at $\mathrm{Ch} 2+948$, with piezometer tip at the rock/overburden interface, Figure 4) recorded an initial drop in water levels of $7 \mathrm{~m}$, which then reached a maximum of $11 \mathrm{~m}$. The drop of groundwater levels probably occurred within hours after the TBM had crossed the folded area but, due to the monitoring routine of the piezometers, this was only recorded the following day.

The fact that dropping of groundwater levels occurred hundreds of metres ahead of the tunnelling works is fully consistent with the expected approximately NW-SE (Figures 3(f) and $3(\mathrm{~g})$ ) elongated shape of the water-bearing sand and gravel strata deposited by the glacier that advanced and retreated along this direction (Figures 3(1) and 5). The fact that the tunnelling did not cause complete dewatering of those strata indicates that they have substantial extension and recharge. It is noted that, non-coincidently, the Ordnance Survey of Ireland (1911a, 1911b) map indicates the location of a water pump at Ch 2+800 (Figure 2).

Piezometric records clearly indicate that, prior to tunnelling, at this location, the bedrock and drift aquifers were not in communication. Therefore it is believed that the dewatering of the sand and gravel strata occurred according to the mechanism schematically illustrated in Figure 10. The tunnelling works caused local failure and deformation of the bedrock above the tunnel crown, which then affected the overlying Boulder Clay, leading to the formation of paths for groundwater from the water-bearing sand and gravel strata to the tunnel face. This caused removal of fine soil particles, vibrodensification and possibly some degree of consolidation of clayey strata.

From $\mathrm{Ch} 2+743$ to $\mathrm{Ch} 2+745$ (rock cover approx. $5 \cdot 2 \mathrm{~m}$ ) the TBM overbroke ahead. Between Ch $2+746$ and Ch 2+758, the TBM crossed medium bedded limestone, steeply dipping $70^{\circ} \mathrm{SE}$. At Ch $2+750$, overbreaks occurred both ahead and up to $2 \mathrm{~m}$ in the crown, with localised water inflow of $120 \mathrm{l} / \mathrm{min}$.

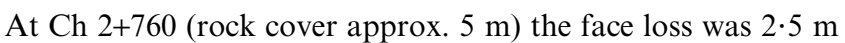
ahead. From $\mathrm{Ch} 2+760$ to $2+787$ (rock cover approx. $4 \cdot 6 \mathrm{~m}$ ) there were systematic problems of face loss ahead and overbreaks due to joint systems, and from $\mathrm{Ch} 2+777$, due to $50^{\circ}$ SE-dipping strata.

From Ch $2+788$ (rock cover approx. $5 \mathrm{~m}$ ) the bedrock beds began to thin and the the dip shallowed to $20-30^{\circ} \mathrm{SW}$. From 


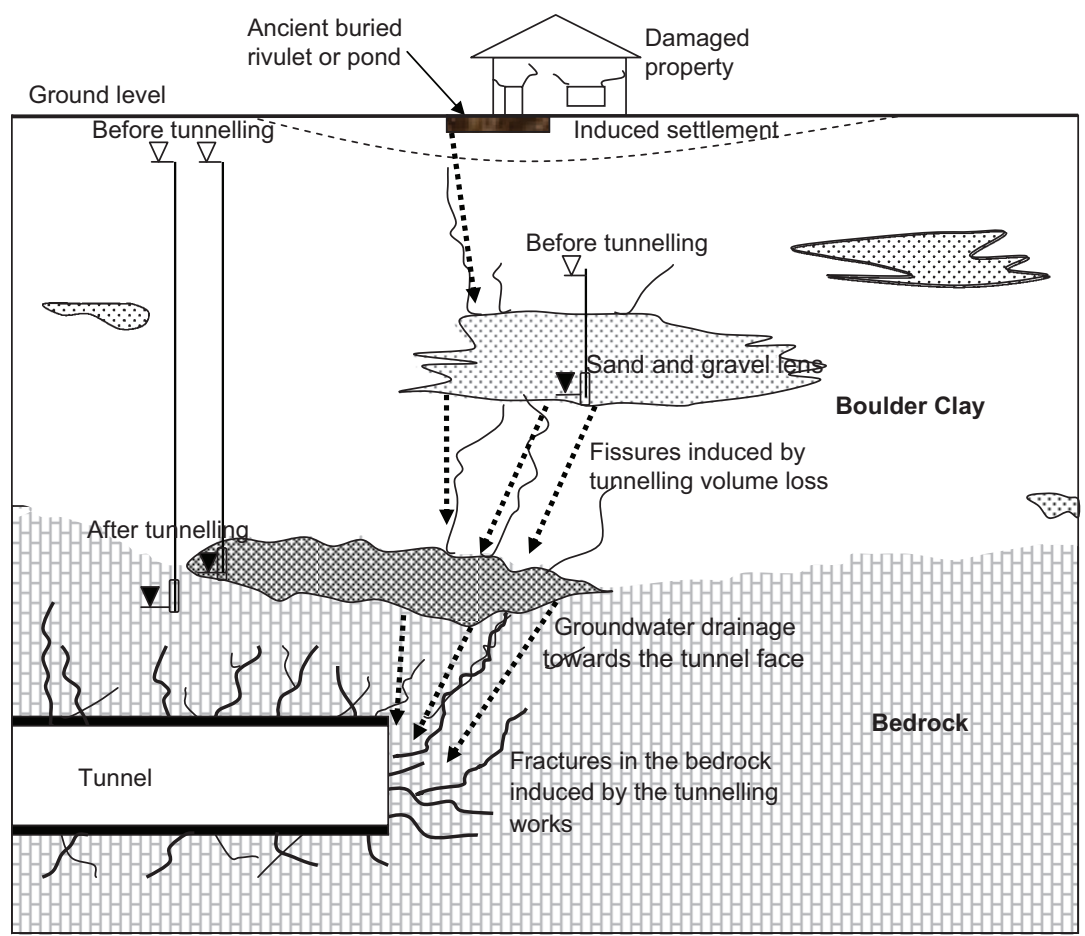

Figure 10. Schematic representation of dewatering of waterbearing gravel and sand lenses embedded within and underneath the Boulder Clay, triggered by tunnelling works

Ch $2+788$ to $\mathrm{Ch} 2+819$, the TMB had considerable difficulties in operating due to the presence of argillaceous mudstone bands rich in smectite (i.e. highly expansive clay) and a high degree of weathering. The presence of smectite had been identified in shale/mudstone bands by a borehole at $\mathrm{Ch} 2+805$ (carried out during the initial studies) that was overlooked.

Once excavated from the face, the mudstone bands dramatically increased in volume (aided by the addition of water at the hopper to suppress dust), turning into limestone gravel/mud muck. The problem become so acute that muck bins reached full capacity and the production had to be halted, allowing further relaxation of the strata on the front face of the tunnel.

From $\mathrm{Ch} 2+819$ to $\mathrm{Ch} 2+942$, the TBM encountered medium to thinly bedded limestone and mudstone $\left(0^{\circ}\right.$ to $\left.20^{\circ} \mathrm{dip}\right)$. Owing to the relatively plastic nature of this type of bedrock, there were no overbreaks. Water inflow was recorded at Ch $2+908$ (114 1/min) and around $\mathrm{Ch} 2+930$ (134 1/min). The rock cover above the tunnel crown passed from $5 \mathrm{~m}$ at $\mathrm{Ch} 2+819$ to $3 \mathrm{~m}$ at $\mathrm{Ch} 2+860$, reducing to $0 \mathrm{~m}$ at $\mathrm{Ch} 2+891,1 \mathrm{~m}$ at $\mathrm{Ch} 2+899,2 \mathrm{~m}$ at $\mathrm{Ch} 2+909,3 \mathrm{~m}$ at $\mathrm{Ch} 2+920,4 \mathrm{~m}$ at $\mathrm{Ch} 2+930$ and $4.8 \mathrm{~m}$ at Ch $2+942$ (Figure 4). The settlement in this area is prevalently related to volume loss caused by the very limited rock cover above the crown of the tunnel and medium to thinly bedded strata not allowing the development of beam and arching effects. It is noted that along this stretch of the tunnel, the maximum settlement at ground level coincides with no rock cover (Figures 4 and 6).

The shape of the bedrock/drift interface along the tunnel alignment may suggest that the extrapolated axis of the buried valley crosses the tunnel alignment $90 \mathrm{~m}$ further north than foreseen (Figures 2 and 6). This represents a change in the direction of the extrapolated buried valley axis (presented in Figure 1) of just a couple of degrees in a clockwise direction.

Settlement in this area was also related to the dewatering that occurred at Ch 2+739, already described above.

From $\mathrm{Ch} 2+943$ to $\mathrm{Ch} 3+060$, the TBM excavated slightly thicker and more frequent limestone strata. A minor fault was encountered at $\mathrm{Ch} 2+986$ with localised water inflow up to 220 1/min. No overbreaks were recorded. The rock cover above the tunnel crown ranged from $7 \cdot 8 \mathrm{~m}$ to $2.4 \mathrm{~m}$ with average around $4 \cdot 5-5 \mathrm{~m}$. It is noted that, from $\mathrm{Ch} 2+981$ to $\mathrm{Ch} 2+989$, despite the rock cover ranging between 2.6 and $2.4 \mathrm{~m}$, no particular intense settlement at ground level was recorded. This is attributed to the greater stiffness of the limestone strata compared to the more plastic and thin strata encountered 
immediately to the north. Settlement was mainly caused by volume loss in combination with the dewatering of the coarse drift strata, which occurred at Ch $2+739$.

From $\mathrm{Ch} 3+061$ to $\mathrm{Ch} 3+200$, the TBM encountered a greater proportion of limestone strata compared to the mudrock. The rock cover ranged from $3.4 \mathrm{~m}$ to $4.6 \mathrm{~m}$ and water inflows were generally very small and concentrated. Between Ch $3+152$ and Ch 3+200 (rock cover $3 \cdot 2-3 \cdot 4 \mathrm{~m}$ ), the TBM encountered weathered and fractured rock with open joints and greater water inflow. Those factors caused an increase in the muck in the TBM cutter-head, resulting in a substantial reduction in production. Settlement at ground level was contained and largely caused by volume loss. At $\mathrm{Ch} 3+188$, the TBM intersected at the axis of a tight fold and water inflow increased to $450 \mathrm{l} / \mathrm{min}$.

From $\mathrm{Ch} 2+600$ to $\mathrm{Ch} 3+800$, the installation of the primary lining proceeded fairly smoothly and water inflow was readily intercepted. The main exception was between $\mathrm{Ch} 3+221$ and Ch $3+291$, where lining rings had some lips and the limited tolerance of the hydrophilic gasket to displacement allowed substantial water inflow in the tunnel. The local dip of the strata suggests that this problem was caused by a sub-vertical fault or tight folds and related fractured rock and running groundwater. The movements in the tunnel lining, between Ch 3+221 and Ch 3+291, did not cause accentuated settlement at ground level, probably because this issue occurred after the installation of the lining.

From $\mathrm{Ch} 3+290$ to $\mathrm{Ch} 3+455$, the recorded settlement at ground level was particularly significant despite the tunnelling works proceeding smoothly and without overbreaks. The rock cover ranged from 4 to $7.9 \mathrm{~m}$ and was over $5 \mathrm{~m}$ along the area where settlement exceeded $10 \mathrm{~mm}$. Therefore, the recorded settlement, especially between $\mathrm{Ch} 3+250$ and $\mathrm{Ch} 3+450$, cannot have been simply caused by volume loss of the ground due to the tunnelling.

In order to identify the magnitude and extent of the settlement at this location (due to factors other than volume loss), transverse settlement data at $\mathrm{Ch} 3+320$ were derived from the settlement contour map (Figure 6). These were then interpolated and plotted to ascertain the approximation of the actual settlement to the reference (immediate settlement) Gaussian distribution curve for the northbound southwards tunnel at the same chainage. The reference Gaussian curve had been calculated according to Peck (1969) and O'Reilly and New (1982) for a predicted volume loss of $0.5 \%$, freefield scenario and the quite homogeneous and isotropic geological conditions proposed in the initial (tender) geological crosssections. It is noted that the 'Gaussian distribution' empirical approach is generally considered suitable for soft soils when the geological sequence is fairly homogeneous and without relevant elements of anisotropy (all assumptions that are quite far removed from the actual site conditions). In hard rock tunnels or mixed conditions (i.e. the site conditions), this approach usually generates conservative results. The limitations of the settlement contour map (Figure 6) have already been described above. All those combined issues limit the reliability of the comparison between the actual and experimental Gaussian curves (Figure 11) presented below.

Figure 11 shows that the actual and predicted Gaussian profiles are clearly different and that the actual settlement distribution is highly asymmetric relative to the tunnel axis.

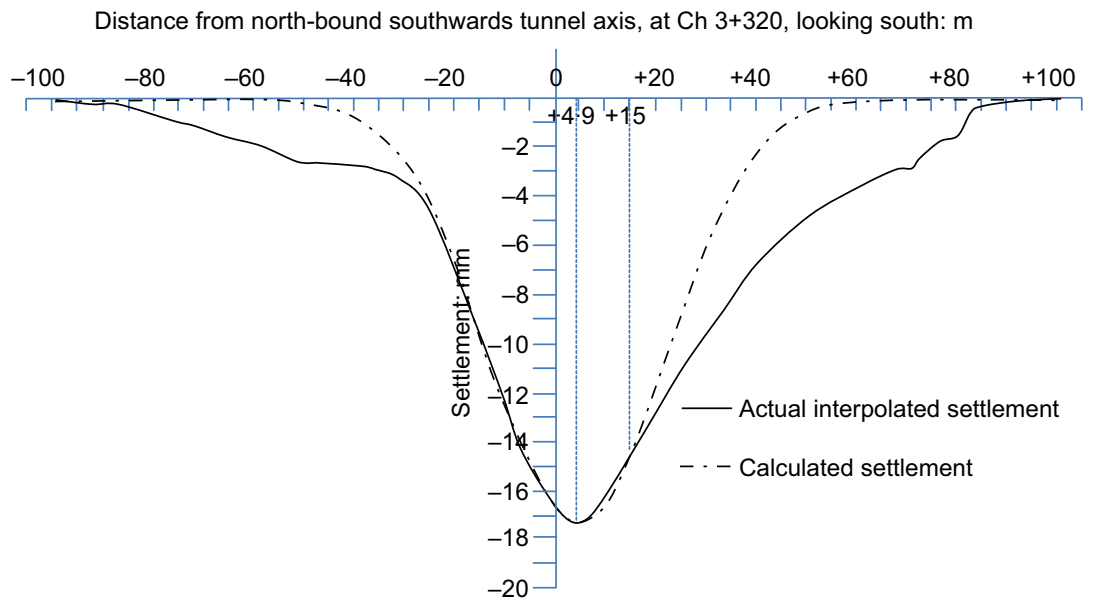

Figure 11. Actual interpolated and calculated transverse Gaussian settlement plot, at DPT northbound Ch 3+320, looking south 
This is related to the fact that the ground conditions are neither homogeneous nor isotropic and to the effect of buildings on the settlement profile. The most significant aspect is the skew of the profile to approximately $4.9 \mathrm{~m}$ west of the tunnel axis. This indicates that settlement is due to a combination of volume loss and other factors. When those are combined, they produce a profile of greater magnitude and lateral extent, evidenced by the divergence of the two profiles west of the $15 \mathrm{~m}$ offset. As the calculated volume loss due to tunnelling is $0.7 \%$ compared to the predicted $0 \cdot 5 \%$, volume loss of the ground is responsible for say $70 \%$ of the settlement, while other causes are responsible for the remaining $30 \%$. However, as the predicted volume loss is expected to be conservative, it is likely that volume loss might be responsible for, say, roughly half of the total recorded settlement only.

At this location, (assuming no surveying errors), the settlement, other than that due to volume loss, is believed to be the result of dewatering of a large body of highly fractured rock located above the crown of the tunnel (Figure 4) with removal of a consistent amount of fine soil particles and possibly vibro-densification. As the tunnel approached this area, the piezometer installed at $\mathrm{Ch} 3+300$ (i.e. BH109, with the piezometer effective length located at the interface between fractured rock and sound rock, see Figure 4) recorded a drop in the water level of over $20 \mathrm{~m}$. Within a few months after the tunnel lining was completed, the piezometric level progressively recovered approximately $4 \mathrm{~m}$. Between $\mathrm{Ch} 3+200$ to $3+490$, water inflow in the tunnel became very recurrent (recorded, say, every 5-10 m) and was typically ranging from $90 \mathrm{l} / \mathrm{min}$ to $325 \mathrm{l} / \mathrm{min}$.

From $\mathrm{Ch} 3+490$, the rock cover progressively increased from $8 \mathrm{~m}$ to over $10 \mathrm{~m}$ and the bedrock mainly included medium strong limestone. Tunnelling progressed smoothly and without overbreaks.

The settlement around $\mathrm{Ch} 3+600$ is attributed to volume loss overlapping to subordinated dewatering, by way of recurrent water inflow into the tunnel from a substantial thickness of sand and gravelly strata embedded in the Boulder Clay. Inperson observations between $\mathrm{Ch} 3+700$ and $3+800$ indicate that water inflow in the tunnel had removed clay, silt and sand from the drift, causing volume loss. At Ch 3+648, water inflow was $500 \mathrm{l} / \mathrm{min}$ and, at $\mathrm{Ch} 3+700$, the TBM crossed a tight fold and water inflow reached $620 \mathrm{l} / \mathrm{min}$. It is noted that the old Ordnance Survey of Ireland (1911a, 1911b) map recorded the presence of a water pump at approximately Ch $3+650$ suggesting the presence of an area of with high groundwater supply. The geological cross-section (Figure 4) shows that, at Ch $3+500$ to $\mathrm{Ch} 3+600$, a thick stratum of sand and gravels is directly overlaid by the made ground. The possibility that the dewatering of this coarse stratum might have triggered consolidation of Boulder Clay and of the overlying made ground and other clayey strata (e.g. ancient lake deposits) is plausible but unlikely. It is noted that the lack of piezometric data for this section of the alignment does not allow 'validation' of this hypothesis.

The settlement between $\mathrm{Ch} 3+700$ and $3+800$ was very contained, probably reflecting the progressive increase of the rock cover above the tunnel crown. Settlement at ground level was cause by volume loss and removal of fine soil particles for the drift (already described above).

\section{Settlement along other sectors of the scheme}

The settlement along the northern section of the TBM tunnel (from $\mathrm{Ch} 2+300$ to $\mathrm{Ch} 2+500$ ) is not comparable to that at the study site (i.e. Ch $2+700$ to $\mathrm{Ch} 3+700$ ), due to the fact that the TBM operated in glacial deposits rather than bedrock.

The settlement along the northbound southward TBM tunnel between $\mathrm{Ch} 2+500$ to $\mathrm{Ch} 2+700$ is comparable to that at the study site due to similar ground conditions. Along this section of the tunnel, settlement was less than $5 \mathrm{~mm}$ and it was mainly related to volume loss of the ground due to tunnelling, with only a negligible component attributed to dewatering of the drift strata.

Settlement along the northbound tunnelling, from $\mathrm{Ch} 3+800$ to $\mathrm{Ch} 4+520$, is only partially comparable with that at the study site, owing to inconsistent ground conditions. South of Ch $3+490$, the thickness of the rock cover above the tunnel crown progressively increases from $8 \mathrm{~m}$ to well over $10 \mathrm{~m}$ (thus substantially improving the arching of the ground). As the tunnelling progressed, the layout of the TBM and the way it was operated were adapted to the ground conditions, thus improving the productivity and addressing the previous issues. Settlement within the residential area of Griffith, located immediately south of the study site, remained contained to less than $5 \mathrm{~mm}$, mainly owing to inevitable volume loss of the ground.

\section{Causes of property damage}

The causes of settlement at ground level, both macroscopic and specific, have been discussed above. The causes of property damage have been investigated on a small scale only, without taking account of how each different damaged building had responded under site-specific soil displacement profiles. Similarly, the building's characteristics and weight, the effect of three-dimensionality, nature of the damage, the effects of the building stiffness on vertical settlement and soil structure interactions have not been considered.

It is noted that papers by Burland and Wroth (1974), Burland (1995), Potts and Addenbrooke (1997), Franzius et al. (2006) 
and Dimmock and Mair (2008) and others have demonstrated the importance of all those factors and showed significant differences in settlement profiles compared to the freefield Gaussian distributions.

Rahman and Orr (2011) have recently presented the use of three-dimensional finite elements coupled with infinite elements to investigate the ground vibrations at the surface in terms of the peak particle velocity due to construction of the northbound DPT. The ground model adopted in that study is fully compatible with the generic ground conditions at Marino described above, although it is simplified to allow the analyses. However, Rahman and Orr's model does not take into account significant factors such as the substantial range of stiffness and variability of the thickness of the rock cover along the tunnel alignment (e.g. stiff and thick limestone strata as opposed to plastic and thinly bedded mudstone, buried valley fracturing the bedrock, faults, tight folds, etc.) or the presence of significant water-bearing sand and gravel strata embedded or underneath the Boulder Clay. The presence of soft and compressible water-laid strata and thick, superficial, made ground was taken into account in the sensitivity analyses by using a range of parameters for the stiffness of the soil. Despite the fact that the empirical models of Rahman and Orr (2011) is inherently crude, it appears to suggest that the TBM's induced ground vibrations were low enough not to cause any damage to (sound) structures at the surface.

On the basis of the ground model and settlement contour map presented here, a number of considerations regarding the causes of property damage, along the study site, can be drawn.

Figure 6 shows that, in general, there is a quite limited correlation and consistency between the position of the damaged properties and the amount of tunnelling related settlement (i.e. $0-20 \mathrm{~mm}$ range). The damaged properties are located in areas with varying amounts of total settlement, including areas with no, or extremely small, recorded total or differential settlement at ground level. This clearly points to the fact that (assuming that no damage was caused by groundborne TBM vibrations or other tunnel construction related causes), at least, some properties were already damaged or in a very precarious structural condition prior to tunnelling.

The properties that have suffered structural damage (Figure 6), and the largest concentration of cosmetically damaged properties at Marino, are both located close to the 10-20 mm settlement area at approximately $\mathrm{Ch} 3+350$. This indicates that, at least locally, there is a clear (although not exclusive) correlation between total and differential settlement and property damage.

More interestingly, Figure 2 shows that, at the study site, virtually all of the properties that have suffered damage lie directly on, or are in close proximity to, post-glacial and historical ponds and rivulets, which are very often oriented in approximately a NW-SE direction (Figures 3(g) and (f)).

The main exception is between $\mathrm{Ch} 3+700$ and $\mathrm{Ch} 3+900$ (Figures 2 and 6). At this location, the damaged properties appear to be systematically located parallel to, but shifted 20 $30 \mathrm{~m}$ southwest of, a rivulet. This strongly suggests that either those properties lie on a rivulet that has not been recorded or there are issues with the historical surveys or in geo-referencing those records.

Another explicable exception of non-correlation between property damage and rivulets is a damaged property that lies in very close proximity to an old sewer tunnel (North Drainage Scheme, Figure 2).

The comparison between Figures 2 and 6 indicates that there is no systematic correlation between the amount of settlement and the location of rivulets and ponds, other than where settlement is over $5 \mathrm{~mm}$. This may suggest that consolidation of clayey pond and rivulet strata might had occurred where settlement due to DPT tunnelling works had been more intense, triggering the dewatering of strata close to ground level (according to the mechanism illustrated in Figure 10).

Figure 6 shows that the position of drumlins (from $\mathrm{Ch} 2+600$ and Ch $3+050$ at the study site) very roughly matches with an area of 'greater' settlement at ground level. This appears coincidental as settlement in this area is clearly related to volume loss. It is noted that in this area, despite great and widespread settlement, there is a remarkably small number of properties that have suffered damage. It is believed that this is related to the fact that these properties were constructed on relic drumlins and therefore founded at higher levels and on more competent ground than properties sitting on backfilled rivulets further south.

A large proportion of the properties at Marino were constructed in the 1920s over a short period of time, and without adequate foundations on made ground fill. The ground investigations and other records for the site show that the fill was placed in an uncontrolled manner (over unstripped soil, stumps, and soft, saturated, highly compressible and plastic fluvial and lacustrine sediments that were high in organic fraction).

This strongly indicates that a number of properties at Marino are founded at a shallow depth on fill placed over historical ponds, rivulets and boggy ground, resulting (i.e. pre-tunnelling) in precarious structural conditions and/or they had already suffered damage. The precarious structural conditions or original damage has been caused by total and/or differential soil settlement due to short- and long-term consolidation, possible failure of very soft and/or water-laid soil and possibly unsuitable foundations. It can 
be expected that weak or already compromised properties (located close to ancient rivulets and ponds) to be substantially more sensitive to damage than structurally sound ones (e.g. those founded on relic drumlins). It is therefore likely that tunnelling works have simply exacerbated existing issues.

This is consistent with what has been historically observed at other locations in Dublin. For instance, the Georgian palaces in central Dublin that are founded almost at ground level (on made ground and soft water-laid strata) have suffered from settlement since their construction. Similarly, some of the eighteenth century buildings of the Dublin Castle complex, founded over the filled moat outside the old walls, had settled appreciably over the centuries (Farrell and Wall, 1990). The same problem has also been evident at St Patrick's Cathedral, which is founded on unstable ground, with the subterranean River Poddle flowing beneath its foundations.

In contrast, the buildings of the Georgian period in central Dublin (which have basements prevalently founded on footings lying 2.5-3 m below ground level, directly on the glacial till) generally do not present settlement damage. It is noted that this type of building generally were not reported to have suffered any appreciable damage following the constructions of the Patrick Street sewer tunnel (Keyes and Kinirons, 1992; Orr and Farrell, 1996), the Grand Canal drainage tunnel and the Grand Canal sewer tunnel (O'Donoghue, 1975; O’Donoghue and White, 1976; Smith, 1983) below central Dublin.

The accurate assessment of the impact of settlement (Figure 6) and vibrations caused by the tunnelling operations on the properties at Marino requires 'building by building' analyses. These would have to take into account the building's pretunnelling structural conditions, the specific ground conditions and all other factors discussed earlier. This kind of analysis, based on a generic ground model, and drawing from DPT experience, has been presented by Murphy et al. (2010) for a historic structure along the proposed Metro North Tunnel route, a few kilometres away from Marino.

\section{Conclusion}

This paper illustrates the importance of preparing an holistic engineering-geological ground model for the study area and the specific site (collating all the available information) to investigate the causes of settlement and property damage. In this particular case, this model included hard evidence (e.g. old topographic maps, borehole logs, groundwater and geotechnical data), as well as soft evidence (e.g. locality names, anecdotal records, general history of the area).

The ground model presented above has proven to be particularly effective in investigating the DPT, as this is a linear infrastructure constructed across a site shaped by tectonic and post-glacial environments. These are, by their very nature, characterised by linear features (e.g. faults, folds, buried valleys, axis of anisotropy of drainage and soil) that can only be fully appreciated by considering the 'big picture' rather than by carrying out spatially limited studies.

The engineering-geological model presented above indicates that the geological conditions north-east of Dublin centre are more complex than what might have been expected by the reconnaissance of the present site. Over the centuries, anthropogenic activities have progressively modified and flattened the landscape which has evolved from the post-glacial rural environment through to urbanisation (Figure 5). Although time and human activities (especially in urban settings) have obliterated most of the visible traces of past environments and processes (e.g. the buried valley crossing Marino area), they have not erased their legacy.

The compiled engineering-geological ground model has been used to investigate property damage related to tunnelling by collating, condensing and overlapping information of various nature into two-dimensional and three-dimensional visual representations. These are easily (almost intuitively) readable and understandable. They also represent an effective method for analysing, comparing, distinguishing and recognising significant data and for extracting key information.

A review of groundwater monitoring and tunnel construction records, in combination with a dedicated ground model, has allowed the identification of, and an explanation for, the tunnel-related causes of settlement at ground level. These mainly include volume loss of the ground due to deformation and, local failure of the tunnel excavation, subordinated dewatering of sand and gravel strata embedded in and beneath the Boulder Clay, with removal of fine soil particles (i.e. clay to sand size), vibro-densification of coarse strata, slow tunnel production and possibly consolidation of the Boulder Clay and superficial clayey strata.

At a macroscopic scale, it is evident that a very large proportion of damaged properties are located in close proximity to rivulets and ponds buried in the 1920 s beneath made ground. The orientation of these rivulets is a result of the advances and retreats of glaciers, which coincide with the main direction of faulting. The correlation between tunnelling, rivulets and ponds, and property damage lies in the fact that structures in precarious structural condition (i.e. founded on soft, water-laid, compressible strata) are inherently more prone to settlement and vibrations related damage than sound ones (founded on relic drumlins). In conclusion, the tunnelling has likely exacerbated already existing issues. 


\section{Acknowledgement}

The author would like to thank Dublin City Council for providing monitoring and tunnel construction data.

\section{REFERENCES}

Bear J (1972) Dynamics of Fluid in Porous Media. Elsevier, New York, NY, USA.

British Parliament (1830) Bill for Draining and Allotting Bogs of Ireland. HMSO, London, UK, Sessional papers, Volume II, No. 262, p. 165.

Burland JB (1995) Assessment of risk of damage to buildings due to tunnelling and excavation. Invited special lecture to 15-Tokio 95. In Proceedings of the 1st International Conference on Earthquake Geotechnical Engineering, Tokyo Ishara K (ed.)). Balkema, Rotterdam, the Netherlands, vol. 3, pp. 1189-1201.

Burland JB and Wroth CP (1974) Settlement of buildings and associated damage. In Proceedings of a Conference on Settlement of Structures. Cambridge, Pentech Press, London, UK, pp. 611-654.

Cater RWG (1982) Sea level changes in Northern Ireland. Proceedings of the Geologists' Association 93(1): 7-23.

Charlesworth JK (1928) The glacial retreat from central and southern Ireland. Quarterly Journal of the Geological Society 84: 293-344.

Clark CD and Meehan RT (2001) Subglacial bedforms morphology of Irish ice sheet reveals major configurations changes during growth and decay. Journal of Quaternary Sciences 16(5): 483-496.

Cooper SM, Gawthorpe RL, Gage M, Fraser AJ and Besly BM (1996) Inversion tectonics of the varioscan foreground of the British Isles. Journal of the Geological Society of London 153: $17-32$.

Corfield SM, Gawthorpe RL, Gage M, Fraser AJ and Besly BM (1996) Inversion tectonics of the Variscan foreland of the British Isles. Journal of the Geological Society of London 153(1): 17-32.

Coxon P (1991) Dublin in the grip of an Ice Age: The Quaternary geology of the Dublin region. Geographical Viewpoint 20: 35-52.

Coxon P (1993) Irish Pleistocene biostratigarphy. Irish Journal of Earth Sciences 12: 85-105.

Coxon P (2001) Cenozoic: Tertiary and Quaternary (until 10,000 years before present). In The Geology of Ireland (Holland CH (ed.)). Dunedin Academic Press, Edinburgh, UK, pp. 388-427.

Coyle DC (1954) The North Dublin drainage scheme. Trans. Inst. Eng. Ireland 80: 107-189.

Creighton JR, Daily D and Reilly TA (1979) The Geology and Hydrogeology of County Dublin, with Particular Reference to the Location of Waste Disposal Sites. Report to Dublin Council. Geological Survey of Ireland, Dublin, Ireland.
d'Alton J (1838) The History of Country Dublin. Hodges and Smith, Dublin, Ireland.

Davies BR (1870) The Environs of Dublin. Charles and C., London, UK, part of a collection of ancient maps presented to the Institution of Civil Engineers of Ireland by P. Cotton.

de Brit TJ (1989) Timing structural events and basemental emplacement using extension veins and cements in the Carboniferous of north central Ireland. Irish Journal of Sciences 10: 13-31.

de Courcy JW (1996) The Liffey in Dublin. Gill and Macmillan, Dublin, Ireland.

de Courcy JW (1998) The Engineering of Dublin. The Dr T. A. McLaughlin Memorial Lecture. The Institution of Engineers of Ireland, Dublin, Ireland.

de Courcy JW (2000) Bluffs, bays and pools in the medieval Liffey at Dublin. Irish Geography 33(2): 117-133.

Devoy RJN (1983) Late Quaternary shoreline in Ireland: an assessment of their implications for isostatic land movement and relative sea-level changes. In Shoreline and Isostasy (Smith DE and Dawson AG (eds)). Academic Press, London, UK, pp. 227-254.

Dimmock PS and Mair RJ (2008) Effect of building stiffness on tunnelling induced ground movement. Tunnelling and Underground Space Technology 23(4): 438-450.

Duncan W (1821) Map. In Historic Dublin Maps. The National Library of Ireland, Ireland.

Eyles N and McCabe AM (1989) Glaciomarine facies within subglacial tunnel valley: the sedimentary record of glacio-isostatic downwarping in the Irish Sea Basin. Sedimentology 36(3): 431-448.

Farrell ER and Wall D (1990) Soils of Dublin. Presented at the meeting between Structure and Construction Section, the Geotechnical Society of Ireland and the Institution of Engineers of Ireland, Republic of Ireland Branch. Transactions of the Institution of Engineers of Ireland 115: 78-97.

Farrell ER, Coxon P, Doff DH and Pried'homme L (1995) The genesis of brown boulder clay of Dublin. Quarterly Journal of Engineering Geology 28(2): 143-152.

Farrington A (1944) The glacial drifts of the district around Enniskerry, County Wicklow. Proceedings of the Royal Irish Academy 50B(6): 133-157.

Farrington A (1949) The glacial drifts of the Leinster mountains. Journal of Glaciology I(5): 220-225.

Farrington A (1957) The Ice Age in the Dublin district. Journal of the Institute of Chemistry of Ireland 5: 23-27.

Featherstone G, Knights M, Lawrence D and Flanaghan J (2003) Dublin Port Tunnel - construction of one of Europe's bigger urban road tunnels. In Proceedings of the Rapid Excavation and Tunnelling Conference (Robinson RA and Marquardt JM (eds)). Society of Mining, Metallurgy, and Exploration, Inc., Litteleton, CO, USA, pp. 770-780. Franzius JN, Potts DM and Burland JB (2006) The response of 
surface structures to tunnel construction. Proceedings of the Institution of Civil Engineers - Geotechnical Engineering 159(1): 3-17.

McConnell B and Philcox ME (1995) Geology of Kildare Wicklow, Sheet 16, scale 1:100,000. Geological Survey of Ireland, Dublin, Ireland.

McConnell B and Philcox ME (1999) Geology of Meath, Sheet 13, scale 1:100,000. Geological Survey of Ireland, Dublin, Ireland.

Gill WD (1962) The Varisican fold belt in Ireland. In Some Aspects of the Varisican Fold Belt (Coe K (ed.)).

Manchester University Press, Manchester, UK, pp. 49-64.

Hanrahan ET (1977) The Irish Glacial Till - Origin and Characteristics. An Foras Forbartha, Dublin, Ireland, R.C.164.

Hoare PG (1975) The pattern of Glaciation of County Dublin. Proceedings of the Royal Irish Academy 75(B): 207-222, plates IV-V.

Hoare PG (1976) Glacial meltwater channels in county Dublin. Proc Royal Irish Academy Biological, Geological and Chemical Sciences 76(B): 176-185.

Hoare PG (1977) The glacial stratigraphy in Shanganagh and adjoining Towland, South-East County Dublin. Proceedings of the Royal Irish Academy 77(B): 295-305, plates I-VIII.

Hoare PG (1991) The glacial stratigraphy and deposits of Eastern Ireland. In Glacial Deposits in Britain and Ireland (Ehlers J, Gippard PL and Rose J (eds)). Balkema, Rotterdam, the Netherlands, pp. 367-375.

Johnston JD (1993) Three-dimensional geometries of veins and their relationship to folds: examples from the Carboniferous of eastern Ireland. Irish Journal of Earth Sciences 12: 47-63.

Jones LG, Sommerville ID and Strongen P (1988) The Lower Carboniferous (Dinatian) of Sword Area: sedimentation and tectonics in the Dublin Basin, Ireland. Geological Journal 23(3): 221-248.

Keyes JM and Kinirons TG (1992) The Patrick Street sewer: design and construction. Transactions of the Institution of Engineers of Ireland 117: 97-109.

Knight J (ed.) (2002) Field Guide to the Coastal Environments of Northern Ireland. University of Ulster, Belfast, UK.

Knight J (2003) Geomorphic and sedimentary evidence for patterns of late Midlandian Ice in Tempo Valley, NorthCentral Ireland. Irish Geography 36(2): 127-144.

Knight J and McCabe AM (1997) Drumlin evolution and ice sheet oscillations along the NE Atlantic margin, Donegal Bay, western Ireland. Sedimentary Geology 111: 57-72.

Lohan R (1994) The Archive of the Office of Public Works and their value for local history. National Archives, Journal of the Irish Society for Archives Autumn: 26-47.

Long M and Menkiti CO (2007) Geotechnical properties of Dublin boulder clay. Géotechnique 57(7): 595-611.
Long M and Murphy B (2003) Difficulties with ground anchorages in hard rock in Dublin, Ireland. Geotechnical and Geological Engineering 21(2): 87-111.

Marchant TR and Sevastopulo GD (1980) The Calp of the Dublin District. Journal of Earth Science and Research, Dublin Society 3(2): 195-203.

Marshall M and Goritshning CO (2003) Dublin Port Tunnelbored update. Tunnels and Tunnelling International June: $44-47$.

McCabe AM (1971) The Glacial Geomorphology of Eastern Counties Meath and Louth, Eastern Ireland. PhD thesis, Trinity College, Dublin, Ireland.

McCabe AM (1972) Direction of Late-Pleistocene ice flow in eastern Counties Meath and Louth, Ireland. Irish Geography 73(B): 443-461.

McCabe AM (1973) The glacial stratigraphy of eastern Counties Meath and Louth. Proceedings of the Royal Irish Academy 73(B): $355-382$.

McCabe AM (1979) East Central Ireland, Field Guide. Quaternary Research Association, Dublin, Ireland.

McCabe AM (1987) Quaternary deposits and glacial stratigraphy in Ireland. Quaternary Science Reviews 6(3): 259-299.

McCabe AM (1991) The distribution and stratigraphy of drumlins in Ireland. In Glacial Deposits in Britain and Ireland (Ehles J, Gibbard PL and Rose J (eds)). Balkema, Rotterdam, the Netherlands, pp. 421-435.

McCabe AM (1993) The 1992 Farrington Lecture: drumlin bedforms and related marginal depositional systems in Ireland. Irish Geography 26(1): 22-44.

McCabe AM and Clark PU (1998) Ice-sheet variability around North Atlantic Ocean during the last glaciation. Nature 392(6674): 373-377.

McCabe AM and Hoare PG (1978) The Late Quaternary history of East Central Ireland. Geological Magazine 115(6): 397413.

McCabe AM and O'Cofaigh C (1995) Late Pleistocene morainal bank facies at Greystone, Eastern Ireland: an example of sedimentation during Ireland marginal re-equilibration in an isostatically depressed basin. Sedimentology 42(4): 647 663.

McConnell B, Philcox M and Geraghty M (2000) Geology of the Meath. A geological description to accompany the bedrock geology 1:100,000 scale Map Series, Sheet 13, Meath. Geological Survey of Ireland, Dublin, Ireland, pp. 1-65.

Meehan RT (1999) Directions of iceflow during the last glaciation in counties Meath, Westmeath and Cavan, Ireland. Irish Geography 32(1): 26-51.

Mitchell GF (1976) The Irish Landscape. Collins, Glasgow, UK. Mitchell F (1981) The Quaternary until 10,000 BP. In A Geology of Ireland (Holland $\mathrm{CH}$ (ed.)). Scottish Academic Press, Edinburgh, UK, pp. 235-238.

Mitchell F, Dickson CF and Dickson JH (1987) Archaeology and 
Environment in Early Dublin. Royal Irish Academy, Dublin, Ireland, Series C, vol. 1.

Murphy J, Gaynor S and Laefer DF (2010) Predicted tunnelinduced settlement and damage to Findlaters church with respect to freefield and constructed side considerations. In GeoFlorida 2010: Advances in Analysis, Modelling, and Design (Fratta DS, Puppala O and Muhunthan B (eds)). American Society of Civil Engineers, Reston, VA, USA. vol. 3, pp. 1690-1699.

Naylon D (1965) Pleistocene and Post-Pleistocene sediment in Dublin Bay. Scientific Proceedings of the Royal Dublin Society A 2(2): 175-188, plates 14-15.

Nicholls H (1929) The construction of a tunnel under the River Liffey. Transactions of the Institution of Engineers of Ireland 60: $85-230$.

Nolan SC (1989) The style and timing of Dinantian synsedimentary tectonics in the eastern part of the Dublin Basin, Ireland. In The Role of the Tectonics in Devonian and Carboniferous Sedimentation in the British Isles (Arthurton RS, Gutteridge P and Nolan SC (eds)). Yorkshire Geological Society, York, UK, Occasional Publication, pp. 83-97.

O'Donoghue DJ (1975) Grand Canal Drainage tunnel design. Transactions of the Institution of Engineers of Ireland $\mathbf{9 8}$ : 114-119.

O'Donoghue DJ and White PR (1976) Grand Canal drainage tunnel: design aspects. Transactions of the Institution of Engineers of Ireland 99: 68-81.

Ordnance Survey of Ireland (1833-1844) Map 18. Ordnance Survey of Ireland, Dublin, Ireland.

Ordnance Survey of Ireland (1843) 140/Dublin City, scale $5 \mathrm{ft}$ to 1 mile (1:1056), (1838) revision. Ordnance Survey of Ireland, Dublin, Ireland.

Ordnance Survey of Ireland (1887) 105 Artane and Conturk, e 268, 269, P2, scale $5 \mathrm{ft}$ to 1 mile (1:1056), by H. Mallin. Ordnance Survey of Ireland, Dublin, Ireland.

Ordnance Survey of Ireland (1888a) 141/1, Drumcondra/Dublin, Ordnance Survey of Ireland, Dublin, Ireland.

Ordnance Survey of Ireland (1888b) 145/1/Drumcondra, Sheet No. XVIII, 6-8, 16-18, 26-28, scale $5 \mathrm{ft}$ to 1 mile (1:1056), by J. H. Kenny Sapper R.E. Ordnance Survey of Ireland, Dublin, Ireland.

Ordnance Survey of Ireland (1907) Co Dublin Sheet XVIII, 29, scale $5 \mathrm{ft}$ to 1 mile (1:1056) 1837, revised map. Ordnance Survey of Ireland, Dublin, Ireland.

Ordnance Survey of Ireland (1908a) Co Dublin Sheet XVIII, 39, scale $5 \mathrm{ft}$ to 1 mile (1:1056) 1837, revised map. Ordnance Survey of Ireland, Dublin, Ireland.

Ordnance Survey of Ireland (1908b) 146/Dublin City/11, No. 18 and 28 , scale $5 \mathrm{ft}$ to 1 mile $(1: 1056)$, (1888) revision. Ordnance Survey of Ireland, Dublin, Ireland.

Ordnance Survey of Ireland (1911a) Sheet XVIII, 4, Dublin. Ordnance Survey of Ireland, Dublin, Ireland.
Ordnance Survey of Ireland (1911b) Sheet XVIII, scale $5 \mathrm{ft}$ to 1 mile (1:1056). Ordnance Survey of Ireland, Dublin, Ireland.

Ordnance Survey of Ireland (1927-1928) Co Dublin Sheet XVIII, 29, scale $5 \mathrm{ft}$ to 1 mile (1:1056) 1837, revised map. Ordnance Survey of Ireland, Dublin, Ireland.

Ordnance Survey of Ireland (1935-1936) Sheet XVIII, scale $5 \mathrm{ft}$ to 1 mile (1:1056), surveyed 1838, revised map. Ordnance Survey of Ireland, Dublin, Ireland.

Ordnance Survey of Ireland (1997) Dublin City and Street Guide, 2nd edn. Ordnance Survey of Ireland, Dublin, Ireland, scale 1:15 000. Ordnance Survey of Ireland, Dublin, Ireland.

Ordnance Survey of Ireland (1999) Discovery Series 50, No. 50 Dublin-Kildare-Meath-Wicklow, scale 1:50,000.

Ordnance Survey of Ireland, Dublin, Ireland.

O'Reilly MP and New BM (1982) Settlement above tunnels in the United Kingdom, their magnitude and prediction. In Proceedings of Tunnelling '82, London. Institute of Mining and Metallurgy, London, UK, pp. 55-64.

Orr TLL and Farrell ER (1996) Geotechnical aspects of tunnelling in soft ground in Ireland. In Geotechnical Aspects of Underground Construction in Soft Ground (Mair R and Taylor N (eds)). Balkema, Rotterdam, the Netherlands.

Peck RB (1969) Deep excavations and tunneling in soft ground. Proceedings of the 7th International Conference on Soil Mechanics and Foundation Engineering, State-of-the-Art Volume, Mexico City, Mexico, pp. 225-290.

Potts DM and Addenbrooke TI (1997) A structure's influence on tunnelling induced ground movements. Proceedings of the Institution of Civil Engineers - Geotechnical Engineering 125(2): 109-125.

Rahman ME and Orr T (2011) Finite element modelling of ground vibrations due to tunnelling activities. International Journal of Civil and Environmental Engineering 3(3): 143-149.

Rocque J (2000) Map [1756]. In Historic Dublin Maps. The National Library of Ireland, Ireland.

Sevastopulo GD (1996) Report on samples from the Dublin Port Tunnel Project. In Dublin Port Tunnel, vol. 5, part 5, section 3.0 on petrographic analysis. Unpublished report.

Skipper J, Follett B, Menkiti CO, Long M and Clarke Series 2 Hughes $J$ (2005) The engineering geology and characterisation of Dublin Boulder Clay. Quarterly Journal of Engineering Geology and Hydrogeology 38(2): 171-187.

Smith W (1983) Grand Canal sewer tunnel completes missing link in Dublin's drainage plan. Tunnels and Tunnelling 15(11): $32-34$.

Sollas WJ (1896) A map to show the distribution of eskers in Ireland. The Scientific Transactions of The Royal Dublin Society 5(13): 785-822.

Swartz M, Misstera BD, Farrell ER, Daly D and Deakin J (1999) The role of subsoil permeability in groundwater vulnerability assessment. Proceedings of the XXIX Congress of the 
International Association of Hydrogeologists, Hydrogeology and Land Use Management, ed. L Melioris Bratislava, Slovak Republic, pp. 523-527.

Sweeney CL (1991) The Rivers of Dublin. Dublin Corporation, Dublin, Ireland.

Synge FM (1979) Quaternary glaciation in Ireland. Quaternary Newsletter 18: 1-18.

Synge FM and Stephens N (1960) The Quaternary Period in Ireland - an assessment. Irish Geography 4: 121-130.

Warren PW (1985) Stratigraphy. In The Quaternary History of Ireland (Edwards KJ and Warren WP (eds)). Academic Press, London, UK, pp. 155-185.

Warren PW (1993) Wicklow in the Ice Age. An Introduction and
Guide to The Glacial Geology of the Wicklow District. Geological Survey of Ireland, Dublin, Ireland.

Warren WP and Ashley GM (1994) Origin of the ice-contact stratified ridges (eskers) of Ireland. Journal of Sedimentary Research A64: 433-449

Whittington RJ (1977) A late-glacial drainage pattern in the Kish bank area and postglacial sediments in the Central Irish Sea. In The Quaternary History of the Irish Sea (Kidson C and Tooley MJ (eds)). Seel House Press, Liverpool, UK, pp. 55-68.

Wright WB and Muff HB (1904) The pre-glacial raisen beach on the south coast of Ireland. Sci Proc Royal Dublin Society, Vol. X.

\section{WHAT DO YOU THINK?}

To discuss this paper, please email up to 500 words to the editor at journals@ice.org.uk. Your contribution will be forwarded to the author(s) for a reply and, if considered appropriate by the editorial panel, will be published as discussion in a future issue of the journal.

Proceedings journals rely entirely on contributions sent in by civil engineering professionals, academics and students. Papers should be 2000-5000 words long (briefing papers should be 1000-2000 words long), with adequate illustrations and references. You can submit your paper online via www.icevirtuallibrary.com/content/journals, where you will also find detailed author guidelines. 